INTERNATIONAL JOURNAL OF

MULTIDISCIPLINARY STUDIES IN ARCHITECTURE

AND CULTURAL HERITAGE

\title{
Study on Decay of Archaeological Wood from Different Environments Using FTIR
}

\author{
Alshimaa Barakat a, Ali Hosney a, Reham Gamal a, Mahmoud Mohamed a, \\ Zainab Abd Elhamed a, Mourad Fawzy a, *
}

\begin{abstract}
The infrared technique was used to analyze 12 samples of soft wood from different locations found in Egypt. Samples were obtained from the sea face from the city of Alexandria in areas Qaitbay castle and the tombs of Kom Al-Shaqafa and the City of Rashid from Al-Manadili house and Azouz Bath, from the center of Egypt from the city of Cairo in areas Ahmed Ibn Tulun Mosque, Rifai Mosque and Mosque and school of Sultan Nasser Hassan and from Upper Egypt from the city of Qena in Al-Omri Mosque in Qus and the city of Esna in Al-Jaddawi Agency to identify the changes in different environments where the wood is generally affected by factors of damage in the surrounding environment, which exceed in pictures Many such as temperature, humidity, salts, air pollutants and microbiological damage represented by micro-organisms and insects. The wood in the desert environment differ from those found in the marine environment, where the high temperatures in the desert environment affect the wood, which leads to oxidation and high degree of acidity both affect the cellulose and lignin. The presence of moisture and salts in the marine environment also affect cellulose and lignin.

\begin{tabular}{ll}
\hline Keywords & \\
- & Wood. \\
- & Cellulose. \\
- & Lignin. \\
$-\quad$ Decay. \\
$-\quad$ FTIR. \\
- $\quad$ Oxidation. \\
Salts. \\
\hline
\end{tabular}
\end{abstract}


INTERNATIONAL JOURNAL OF

MULTIDISCIPLINARY STUDIES IN ARCHITECTURE

AND CULTURAL HERITAGE

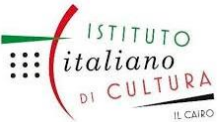

\section{Introduction}

Wood is a porous organic material that absorbs and maintains moisture. It is also a corrosive material that takes different conditions in its growth in response to external influences. It comes from wood plants, specifically trees, shrubs and wood. The wood is mainly composed of $40-44 \%$ cellulose and $15-35 \%$ hemicellulose and is associated with lignin $18-35 \%$; this is the general structure of wood and its types. During outdoor exposure, wood can undergo severe changes of its physical and structural properties due to the combined effect of sunlight, oxygen, moisture, atmospheric pollutants and micro- organisms. The combination of oxygen and solar radiation rapidly induce oxidation of lignin and hemicelluloses and polymerization of cellulose. The wood is divided according to its kindto soft wood and hard wood. In this work, the changes that occur in the soft wood will bedealt with as a result of the damage caused by the damage factors in the surrounding environment. FTIR spectroscopy was used to examine changes of chemical components of wood. The relationship between the changes of chemical components was also investigated. (Shi, Xing, \& Lia, 2012) .FTIR absorbance spectra versus wave number between $4000-400 \mathrm{~cm}-1$ (Jelle \& Hovde, 2012). FTIR spectroscopy is a frequently used technique in various scientific and applied fields. (Naumann, Kües, Polle, Peddireddi, \& S, 2007). The characteristic functional groups of cellulose are strong broad O?H stretching at 3300$3600 \mathrm{~cm}-1$, the functional group $\mathrm{O}-\mathrm{H}$ is the indicator of the hygroscopic properties of wood. It expresses the water molecules bound by hydrogen bonds. The FTIR spectra show $\mathrm{C}-\mathrm{H}$ stretching band in methyl and methyl groups at $3000-2800 \mathrm{~cm}-1$. Asymmetric $\mathrm{CH} 2$ stretching between 2935-2915 cm-1 and symmetric $\mathrm{CH} 2$ stretching between2865-2845 cm-1, but Asymmetric $\mathrm{CH} 3$ stretching between $2970-2950 \mathrm{~cm}-1$ and symmetric $\mathrm{CH} 3$ stretching between $2880-2860 \mathrm{~cm}-1$, C$\mathrm{H}$ bending between $1480-1370 \mathrm{~cm}-1$. The band at around $1420-1430 \mathrm{~cm}-1$ is designated as 


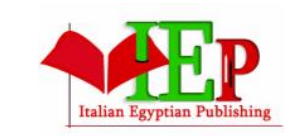

ISSN: $2735-4415$
INTERNATIONAL JOURNAL OF

MULTIDISCIPLINARY STUDIES IN ARCHITECTURE

AND CULTURAL HERITAGE

VOLUME 1, ISSUE 1, 2018, $146-196$.

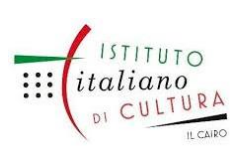

www.egyptfuture.org/ojs/

associated with the amount of crystalline structure of the cellulose; while the band at $898 \mathrm{~cm}-1$ is assigned to the amorphous region in cellulose. The band between $1150-1165 \mathrm{~cm}-1$ is C-O-C stretching, which expresses the cellulose polymerization. (Lionetto, F; Sole, R; Cannoletta, D; Vasapollo, G; Maffezzoli , A; 2012) (Poni, 2007)(Gupta, Jelle, \& Gao, 2014). (Shi, Xing, \& Lia, 2012). (Kavkler \& Demsar, 2012). (Younis, 2016). (Fawzy, 2016)(Poletto, Zattera, \& Santana, 2012). The characteristic functional groups of hemicelluloses are similar to those found in cellulose where hemicellulose contains the hydroxyl group $(\mathrm{O}-\mathrm{H})$ and the hydrocarbon group (C$\mathrm{H})$. In addition to the carbonyl group $(\mathrm{C}=\mathrm{O})$. (Younis, 2016). The band between $1740-1730 \mathrm{~cm}-1$ is associated $\mathrm{C}=\mathrm{O}$ vibration of esters, ketones, aldehydes in hemicellulose (Traoré , $\mathrm{M}$; Kaal, J; Cortizas, A; 2016). (Fawzy, 2016). (Shi, Xing, \& Lia, 2012). (Gupta, Jelle, \& Gao, 2014). (Poni, 2007). (Wozniak, Ratajczak, szentner, Kwasniewska, \& Mazela, 2015). (Müller, Schöpper, t Vos, Kharazipour, \& Polle, 2009). (Pandey \& Pitman, 2003)(Anderson, Pawlak, Owen, \& Feist, 1991). The band at $1735 \mathrm{~cm}-1$ is assigned to $C=0$ stretching vibrations of the carboxyl and acetyl groups in hemicellulose. (Poletto, Zattera, \& Santana, 2012). The characteristic functional groups of lignin are similar with cellulose and hemicellulose in contains a total hydroxyl group and hydrocarbon group lignin also contains a group of aromatic hydrocarbon group which is the most important characteristic of lignin when analyzing infrared spectroscopy. The band between $3100-3000 \mathrm{~cm}-1$ is assigned to aromatic $\mathrm{C}-\mathrm{H}$ stretching. They are weak in lignin and do not appear in the spectroscopy of wood. The band between $1515-1505 \mathrm{~cm}-1$ is assigned to $\mathrm{C}=\mathrm{C}$ (Poletto, Zattera, \& Santana, 2012). (Fawzy, 2016). (Younis, 2016). (Kavkler \& Demsar, 2012). (Pandey \& Pitman, 2003). (Gupta, Jelle, \& Gao, 2014). (Jelle \& Hovde, 2012). 1504cm-1 aromatic skeletal vibrations guaiacyl rings. (Traoré, Kaal, \& Cortizas, 2016). The processes of oxidation and hydrolysis of cellulose break down the chemical chains, which in turn has a significant effect on the change in the physical and chemical properties of cellulose and lignin in general, as wood is easy to react and quickly oxidized to yellow brownish in addition to acid compounds (El Hadidi, 1997), where the wood when exposed to heat the initial stage is the moisture evaporation in the 


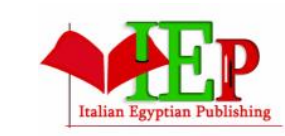

ISSN: $2735-4415$
INTERNATIONAL JOURNAL OF

MULTIDISCIPLINARY STUDIES IN ARCHITECTURE

AND CULTURAL HERITAGE

VOLUME 1, ISSUE 1, 2018, $146-196$.

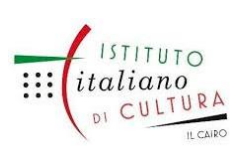

www.egyptfuture.org/ojs/

range $20-120^{\circ} \mathrm{C}$. Depending on the wood type and gaseous atmosphere, the temperature at which the process ends varies in the range between $100-126^{\circ} \mathrm{C}$. This phase is endothermic as energy is used for the drying process of the sample. The mass loss during this stage represents $7-15 \%$ of the whole sample mass. The second stage corresponds to the devolatilization process (emission of volatile compounds).(Maryandyshev, et al., 2016), which take place in the decomposition of the polymer structure in lignin and starts at relatively low temperatures, of $200-275^{\circ} \mathrm{C}$, the main process occurring around $400{ }^{\circ} \mathrm{C}$, with the formation of aromatic hydrocarbons, phenolic, hydroxyl phenol and guaiacyl-/syringyl-type compounds, most products having phenolic $\mathrm{OH}$ groups. The $\mathrm{C}=\mathrm{O}$ stretching band at $1740-1720 \mathrm{~cm}-1$ can decrease, due to degradation of acetyl groups. Moreover, a shoulder around $1730 \mathrm{~cm}-1$ can be due to oxidized cellulose and lignin. ( Lionetto, Del Sole, Can, \& Maffezzoli, 2012). Changes in lightness of wood during heat treatment are mainly due to the hemicellulose degradation, and wood color becomes darker starting from the beginning of heat treatment. The degradation of hemicelluloses intensifies with increasing heat treatment temperature ( Kocaefe, Huang, Kocaefe , \& Boluk, 2013). Moisture, which is often the cause of the start of chemical reactions and have a large role in that damage where we find that the wood absorbs moisture and when the high temperature of the water evaporates a large amount of precipitation of salt on the wood and inside. (Held, Jurgens, Duncan, \& Farrell, 2006). The effect of the content of inorganic fillers of wood, estimated in the conventional analysis as ashes, is very relevant in the ATR-FTIR spectra, considering that some of these components evidence absorbing peaks in important regions of the spectrum, thus hiding or strongly influencing the signals coming from structural components of wood( Pizzo, Alves, Macchioni, \& Giachi, January 2008). Maximum moisture content and basic density are two scientific and relatively more easily operated Indicators for the degradation degree of waterlogged wood. Waterlogged wood is usually divided into 3 categories according to its preservation states: - Category I, maximum moisture content $\geq 400 \%$, severe degradation; Category II, $400 \%$ > maximum moisture content $>185 \%$, moderate 


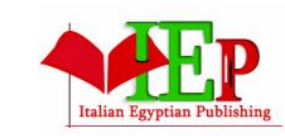

ISSN: $2735-4415$
INTERNATIONAL JOURNAL OF

MULTIDISCIPLINARY STUDIES IN ARCHITECTURE

AND CULTURAL HERITAGE

VOLUME 1, ISSUE 1, 2018, $146-196$.

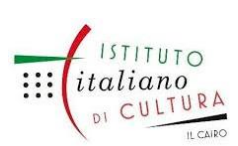

www.egyptfuture.org/ojs/

degradation; - Category III, maximum moisture content $\leq 185 \%$, mild degradation.( Jingran, Jian, Jian, \& Menglin, (2014)) .The effect of mould fungi the mould fungi growth and wood rot decay makes chemical changes and physical changes such as (the actual thickness and a thin surface layer) the band of $1558 \mathrm{~cm}-1$ and $1535 \mathrm{~cm}-1$. Makes changes in the chemical bonds, and that's the source for the absorbance peaks at these wave numbers ( Jelle \& Hovde2, Fourier Transform Infrared Radiation Spectroscopy Applied forWood Rot Decay and Mould Fungi Growth Detection, 2012). The effect of different fungi (Cladiosporium sp., Alternaria sp. and Aureobasidium sp.): broad $3300-2500 \mathrm{~cm}-1$ for bonded $\mathrm{O}-\mathrm{H}$ stretching vibration, shoulders at 2800- $2500 \mathrm{~cm}-1$ for overtones and coupling between $\mathrm{O}-\mathrm{H}$ in-plane bending and $\mathrm{C}-\mathrm{O}$ stretching vibration region of fatty acid, $1700-1600 \mathrm{~cm}-1$ for carbonyl and $\mathrm{C}=\mathrm{O}$ stretching vibration of amide I, 1620-1500 cm-1(Gupta b. , Jelle, Hovde, \& Holme, 2011). Salts are one of the chemical factors affecting the wood, as many of the inorganic salts disintegrate in water solutions and make the solution acidic or alkaline weak or strong and the effect of this solution on wood depends on the degree of concentration of salt and the degree of water. ( Unger, Schniewind, \& Unger, 2001). Acid salts significantly affect carbohydrates in cellulose and hemicellulose in wood. Lignin shows significant resistance to acid effect and results in a significant reduction in wood tension strength, unlike alkaline salts that affect lignin. In general, the effect of alkali on wood is greater than that of acid at high concentrations and high temperature. But the acidity and alkalinity of salt is not the only indicator of its effect on the chemical composition of wood. This is evidenced by the strong effect of both water-calcium sulfate and sodium chloride salt, although it is a neutral salt. Sodium chloride salt has a low effect on the degree of cellulose polymerization by reducing the density of $\mathrm{C}-\mathrm{O}-\mathrm{C}$ stretching there is a change in the density and shape of the distinctive spectrum of crystallization of cellulose in the absorption area $1425 \mathrm{~cm}-1$, indicating the effect of salt on the degree of crystallization of cellulose and affects the hemicellulose, where the distinctive spectrum of hemicellulose disappears and significantly affects the lignin and especially the syringyl lignin in the absorption area 1595-1605 cm-1, but its 
effect on the guaiacyl lignin is less in the absorption area 1504-1515 cm-1 (Younis, 2016). Salt Notron most salts destroy the area of hemicellulose and lignin more than cellulose, but the effect of salt water calcium sulfate is greater than the effect of sodium chloride and Notron salt and in general, the salts significantly affect the hemicellulose and lignin more than the cellulose (Younis, 2016). Salts lead to a series of chemical reactions that lead to the deteriorate cellulose, hemicellulose and lignin, and lead to a break in the middle plate leading to the end of the appearance of fiber decay and is a gradual damage occurs at the beginning on the surface of the wood and then gradually moves to the inner cells if the weather conditions are reasonable. (Anderson, Pawlak, Owen, \& Feist, 1991)(Fawzy, 2016)(Younis, 2016)(El Hadidi, 1997).

\section{Methods:}

Microscopic inspection. ROHAS Digital Microscope 1200X.

FTIR. Nicolet 380 FT-IR Spectrometer. Solid Sample -Bromide Technique. Results and discussion.

\section{RESULTS AND DISCUSSION}

-Field study of the effect of various damage factors on the chemical composition of wood in different environments in Egypt.

-A total of 12 samples were tested and analyzed from northern, central and southern Egypt.

During the selection of samples it was observed that the sample were:

1. Completely damaged.

2. Mixture for building materials (stone and mortar) or bricks, bricks and mortar bricks were mixed with the wood components. 
3. Mixed with salt crystals (samples from northern Egypt).

Documentation was done using a digital camera and the use of a digital microscope 1200x in situ. Analyses were done using infrared spectroscopy

\section{RESULTS AND DISCUSSION}

-Field study of the effect of various damage factors on the chemical composition of woodin different environments in Egypt.

-A total of 12 samples were tested and analyzed from northern, central and southern Egypt.

During the selection of samples it was observed that the sample were:

1.Completely damaged.

2.Mixture for building materials (stone and mortar) or bricks, bricks and mortarbricks were mixed with the wood components.

3.Mixed with salt crystals (samples from northern Egypt).

Documentation was done using a digital camera and the use of a digital microscope 1200x insitu. Analyses were done using infrared spectroscopy

\section{Samples from North of Egypt}

Alexandria" Qaitbay castle and Kom Al-Shaqafa tombs "

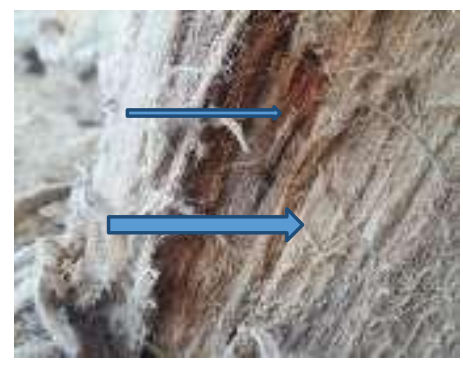


Figure (1-1) shows the bottom window frames of one of the windows of the coastal corridor of Qaitbay Castle. The figure shows thefragmentation and separation of the wood surface and the accumulation of salts because its proximity to the sea.

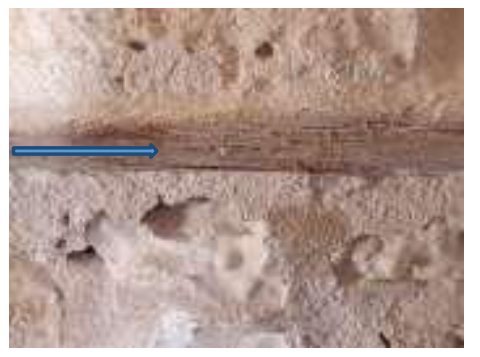

Figure (1-2) shows one of the wooden beams inside the sandstone wall on the floor. The wood surface is damaged and the fiber is broken by the salts and the resulting pressure.

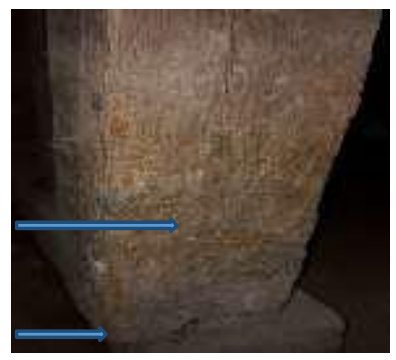


Figure (1-3) shows one of the wooden pillars inside thetombs of Kom Al-Shaqafah, which suffer from biologicaldamage, crushing, splitting and cracks resulting from the pressure on it.

These figures shows that defiberation and biological deterioration such as (some tunnels andholes) as a result to salts and highly humidity.

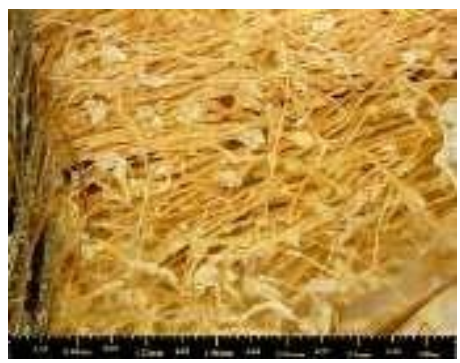

Figure (1-4) digital microscope detail of figure (1-1) shows defiberation andcrystallization of salts on cellulose fibers.

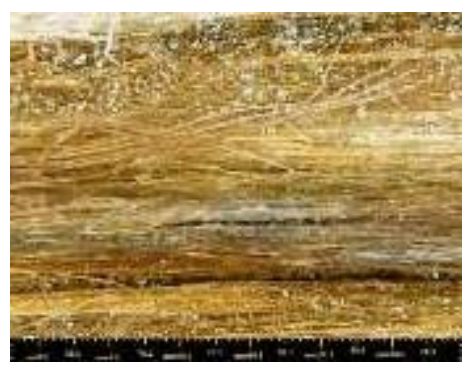


Figure (1-5) digital microscope detail of figure(1-2) shows salt crystals found on the surface of wood and defibration resulting from the effect of salts.

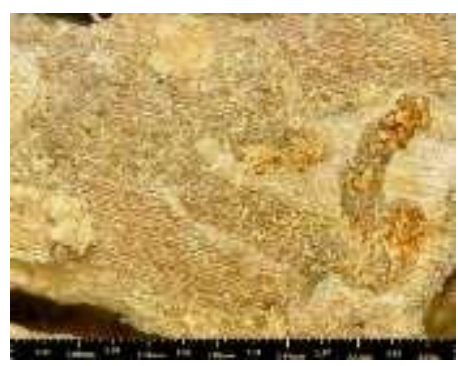

Figure (1-6) digital microscope detail of figure (1-3) shows that wood suffers from holes and tunnels caused by biol.

Digital microscope images show that defibration, and salts crystals occur expand in the wood, the wood turns to the powder and it have an effect on lignin and hemicellulose more than cellulose because of humidity and salts. 
INTERNATIONAL JOURNAL OF

MULTIDISCIPLINARY STUDIES IN ARCHITECTURE AND CULTURAL HERITAGE

VOLUME 1, ISSUE 1, 2018, $146-196$.

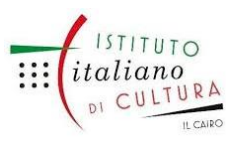

www.egyptfuture.org/ojs/

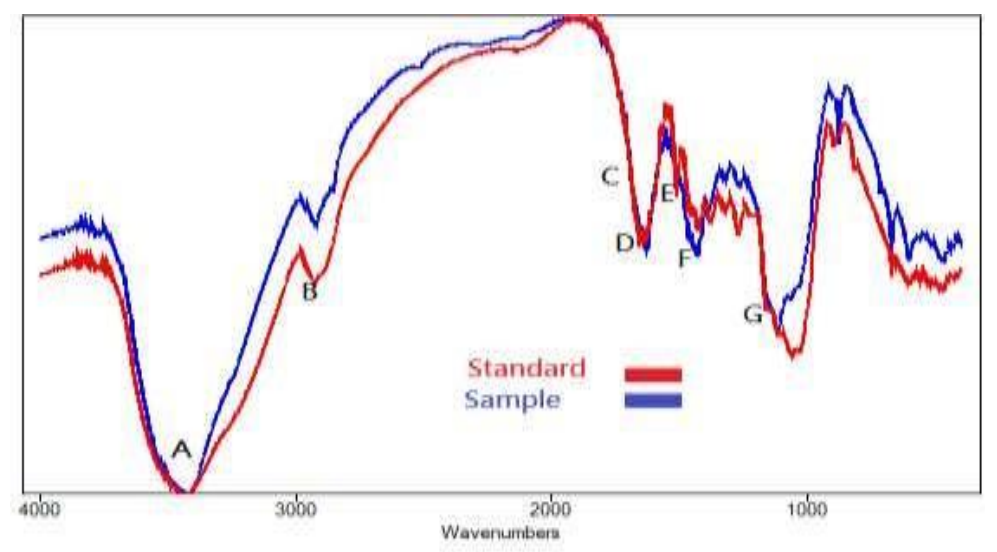

Fig.1-7 FTIR spectra for wooden surface from $a$ window the first floor in Qaitbay castle.

Table "1"The FTIR analysis results of wood sample.

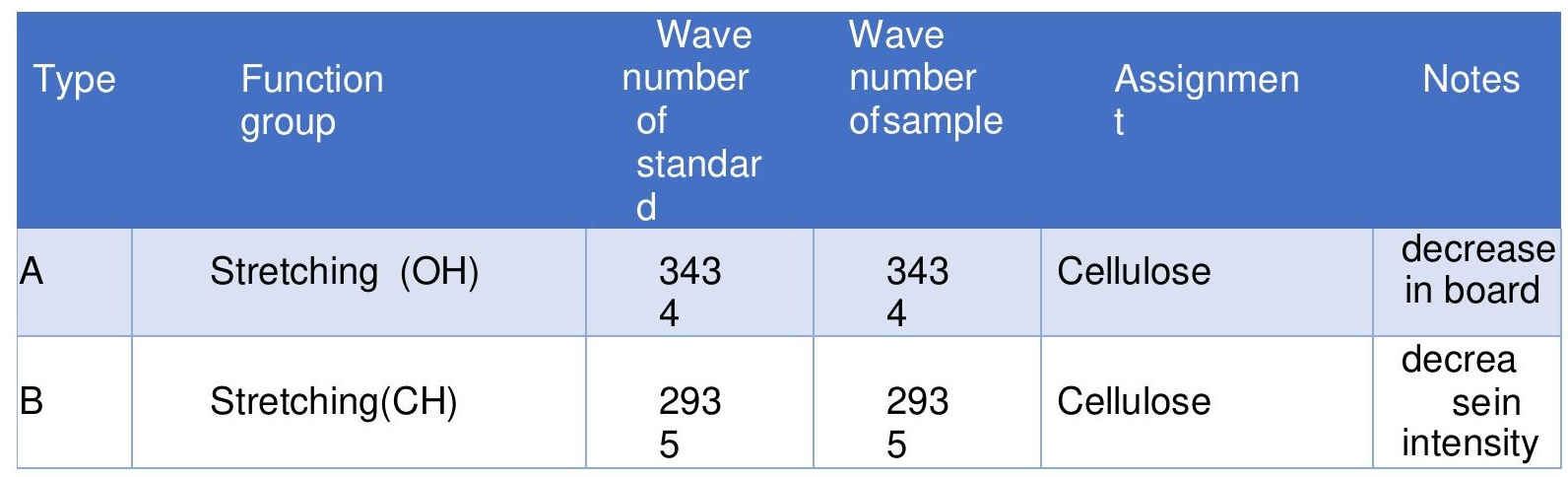

156 


\begin{tabular}{|c|c|c|c|c|c|}
\hline C & $\begin{array}{l}\text { Stretching }(\mathrm{C}=\mathrm{O}) \\
\text { conjugated }\end{array}$ & $\begin{array}{l}173 \\
8\end{array}$ & $\begin{array}{l}173 \\
8\end{array}$ & Hemicellulose & $\begin{array}{l}\text { No } \\
\text { change }\end{array}$ \\
\hline D & $\begin{array}{l}\text { Stretching }(\mathrm{C}= \\
\text { O) } \\
\text { Unconjugated }\end{array}$ & $\begin{array}{l}165 \\
4\end{array}$ & $\begin{array}{l}165 \\
4\end{array}$ & $\begin{array}{l}\text { Cellulose } \\
\text { oxidation }\end{array}$ & $\begin{array}{l}\text { Increas } \\
\text { ein } \\
\text { intensity }\end{array}$ \\
\hline $\mathrm{E}$ & Stretching $(\mathrm{C}=\mathrm{C})$ & $\begin{array}{l}151 \\
3\end{array}$ & $\begin{array}{l}151 \\
0\end{array}$ & Lignin & $\begin{array}{l}\text { decrease } \\
\text { in } \\
\text { intensit } \\
y\end{array}$ \\
\hline $\mathrm{F}$ & Bending $(\mathrm{CH})$ & $\begin{array}{l}142 \\
5\end{array}$ & $\begin{array}{l}142 \\
3\end{array}$ & $\begin{array}{l}\text { Cellulose } \\
\text { crystallinit } \\
\text { y }\end{array}$ & $\begin{array}{l}\text { increas } \\
\text { ein } \\
\text { intensity }\end{array}$ \\
\hline G & $\begin{array}{l}\text { Stretching (C-O- } \\
\text { C) }\end{array}$ & $\begin{array}{l}116 \\
1\end{array}$ & $\begin{array}{l}116 \\
1\end{array}$ & $\begin{array}{l}\text { Cellulose } \\
\text { polymerizatio } \\
\mathrm{n}\end{array}$ & $\begin{array}{l}\text { decrea } \\
\text { sein } \\
\text { intensit } \\
y \\
\text { and } \\
\text { board }\end{array}$ \\
\hline
\end{tabular}

Fig.1-7 FTIR spectra shows that decrease in board in $(\mathrm{OH})$ stretching at $3434 \mathrm{~cm}^{-1}$ due to increase in $\mathrm{C}=\mathrm{O}$ stretching in the absorption area $1654 \mathrm{~cm}^{-1}$ indicating the oxidation processin cellulose as a result of heat, increase in intensity in $(\mathrm{CH})$ bending at $1423 \mathrm{~cm}^{-1}$ indicates a change in the degree of crystallization of cellulose and decreasing in intensity $(C=C)$ stretching at $1510 \mathrm{~cm}^{-1}$ indicates a decrease in the rate of lignin due to the effect of salts. 


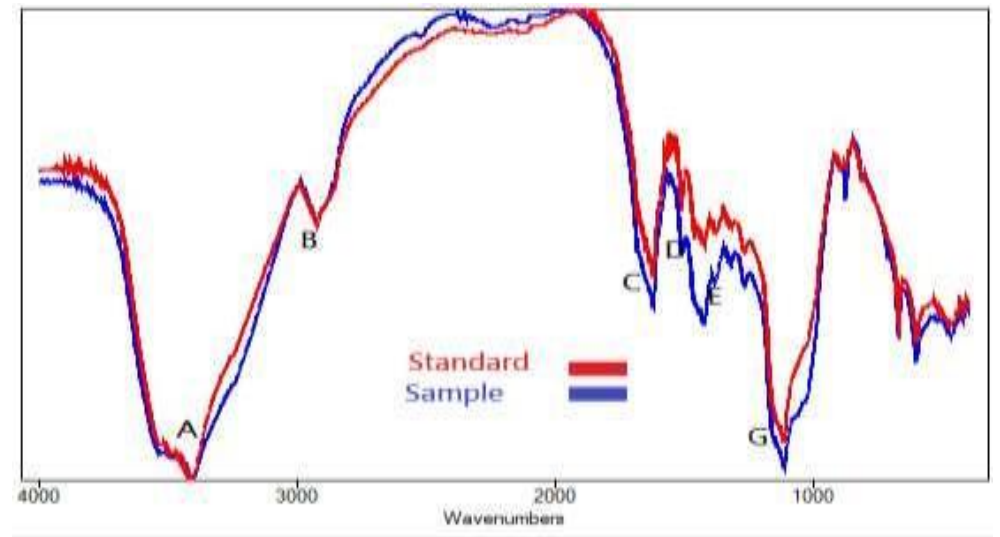

Fig.1-8 FTIR spectra for wooden surface from a wooden brace in the middle of the wall betweenlimestones in Qaitbay castle.

Table "2"The FTIR analysis results of wood sample. 


\begin{tabular}{|c|c|c|c|c|c|}
\hline Type & $\begin{array}{l}\text { Function } \\
\text { Group }\end{array}$ & $\begin{array}{l}\text { Wave } \\
\text { number } \\
\text { of } \\
\text { standard }\end{array}$ & $\begin{array}{l}\text { Wave } \\
\text { number } \\
\text { ofsample }\end{array}$ & $\begin{array}{l}\text { Assignmen } \\
t\end{array}$ & $\begin{array}{l}\text { Note } \\
\mathrm{s}\end{array}$ \\
\hline A & Stretching $(\mathrm{OH})$ & $\begin{array}{l}340 \\
8\end{array}$ & $\begin{array}{l}340 \\
8\end{array}$ & Cellulose & $\begin{array}{l}\text { Increase in } \\
\text { board }\end{array}$ \\
\hline B & Stretching $(\mathrm{CH})$ & $\begin{array}{l}292 \\
0\end{array}$ & $\begin{array}{l}292 \\
0\end{array}$ & Cellulose & No change \\
\hline C & $\begin{array}{l}\text { Stretching }(C=O) \\
\text { Unconjugated }\end{array}$ & $\begin{array}{l}163 \\
0\end{array}$ & $\begin{array}{l}163 \\
0\end{array}$ & $\begin{array}{l}\text { Cellulose } \\
\text { oxidation }\end{array}$ & $\begin{array}{l}\text { Increase in } \\
\text { intensity }\end{array}$ \\
\hline D & Stretching $(\mathrm{C}=\mathrm{C})$ & $\begin{array}{l}151 \\
0\end{array}$ & $\begin{array}{l}151 \\
0\end{array}$ & Lignin & $\begin{array}{l}\text { Decrease in } \\
\text { intensity }\end{array}$ \\
\hline $\mathrm{E}$ & $\begin{array}{l}\text { Bending }(\mathrm{CH})+ \\
\mathrm{CaCO}_{3}\end{array}$ & $\begin{array}{l}142 \\
4\end{array}$ & $\begin{array}{l}142 \\
6\end{array}$ & $\begin{array}{l}\text { Cellulose } \\
\text { crystallinity }\end{array}$ & $\begin{array}{l}\text { Increase in } \\
\text { intensity }\end{array}$ \\
\hline G & $\begin{array}{l}\text { Stretching (C-O- } \\
\text { C) }\end{array}$ & $\begin{array}{l}115 \\
8\end{array}$ & $\begin{array}{l}115 \\
8\end{array}$ & $\begin{array}{l}\text { Cellulose } \\
\text { polymerizatio } \\
\text { n }\end{array}$ & $\begin{array}{l}\text { Increase in } \\
\text { intensity }\end{array}$ \\
\hline
\end{tabular}

Fig.1-8 FTIR spectra shows that increase in board in $(\mathrm{CH})$ bending at $1426 \mathrm{~cm}^{-1}$ resulting from the presence of spectrum of carbonate range $\left(\mathrm{CaCO}_{3}\right)$ in this region and decrease in intensity in $(\mathrm{C}=\mathrm{C})$ stretching at $1510 \mathrm{~cm}^{-1}$ indicates a decrease in the rate of lignin due to the effect of salts. 


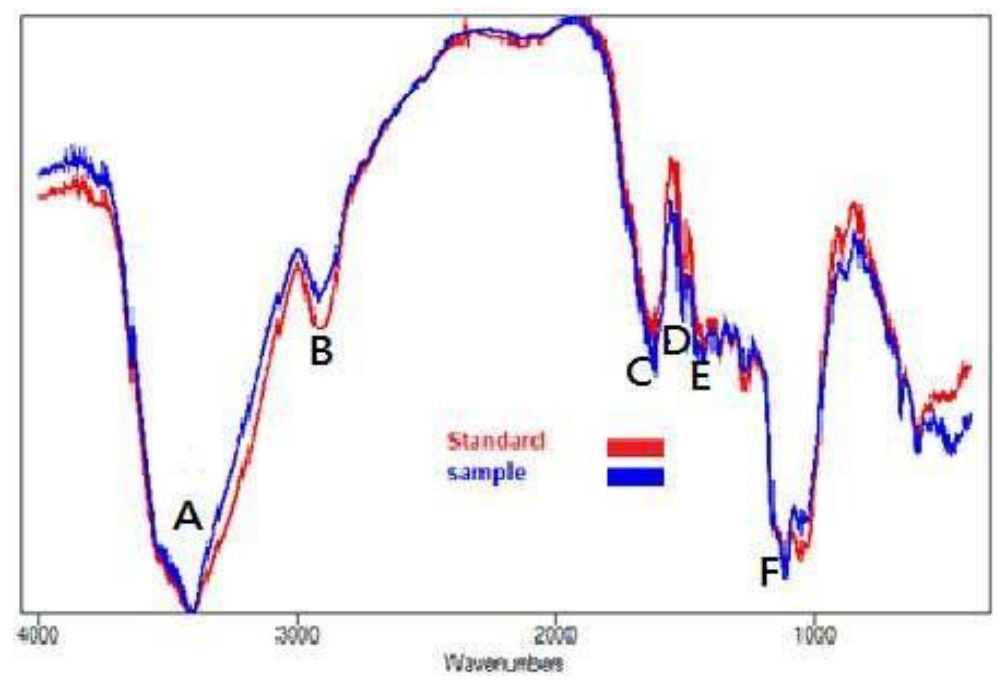

Fig.1-9 FTIR spectra for wooden surface from a wooden brace in the tombs of Kom Al-Shaqafah. 


\begin{tabular}{|c|c|c|c|c|c|}
\hline Type & $\begin{array}{l}\text { Function } \\
\text { group }\end{array}$ & $\begin{array}{l}\text { Wave } \\
\text { number } \\
\text { of } \\
\text { standar } \\
d\end{array}$ & $\begin{array}{l}\text { Wave } \\
\text { number } \\
\text { ofsample }\end{array}$ & $\begin{array}{l}\text { Assignmen } \\
t\end{array}$ & $\begin{array}{l}\text { Note } \\
\mathrm{s}\end{array}$ \\
\hline A & Stretching(OH) & 3403 & $\begin{array}{l}340 \\
3\end{array}$ & Cellulose & $\begin{array}{l}\text { Decrease in } \\
\text { board }\end{array}$ \\
\hline B & Stretching $(\mathrm{CH})$ & 2915 & $\begin{array}{l}291 \\
5\end{array}$ & Cellulose & $\begin{array}{l}\text { decrease in } \\
\text { intensity }\end{array}$ \\
\hline C & $\begin{array}{l}\text { Stretching }(\mathrm{C}=\mathrm{O})(\mathrm{H}- \\
\mathrm{O}- \\
\mathrm{H})\end{array}$ & 1635 & $\begin{array}{l}163 \\
5\end{array}$ & $\begin{array}{l}\text { Cellulose } \\
\text { Oxidation }\end{array}$ & $\begin{array}{l}\text { Increase in } \\
\text { intensity }\end{array}$ \\
\hline D & Stretching $(\mathrm{C}=\mathrm{C})$ & 1514 & $\begin{array}{l}151 \\
1\end{array}$ & Lignin & $\begin{array}{l}\text { Decrease in } \\
\text { intensity }\end{array}$ \\
\hline$E$ & Bending $(\mathrm{CH})$ & 1425 & $\begin{array}{l}142 \\
5\end{array}$ & $\begin{array}{l}\text { Cellulose } \\
\text { crystallinit } \\
\text { y }\end{array}$ & No change \\
\hline $\mathrm{F}$ & Stretching $(\mathrm{C}-\mathrm{O}-\mathrm{C})$ & 1158 & $\begin{array}{l}115 \\
8\end{array}$ & $\begin{array}{l}\text { Cellulose } \\
\text { polymerizatio } \\
\mathrm{n}\end{array}$ & No change \\
\hline
\end{tabular}

Table "3"The FTIR analysis results of wood sample.

Fig 1-9 FTIR spectra shows that decrease in board in $(\mathrm{OH})$ stretching at $3403 \mathrm{~cm}^{-1}$ is due to increase in $\mathrm{C}=\mathrm{O}$ stretching in the absorption area 1635 $\mathrm{cm}^{-1}$ indicating the oxidation process in cellulose as a result of heat and decrease in intensity in $(\mathrm{C}=\mathrm{C})$ stretching at $1511 \mathrm{~cm}^{-1}$ indicates a decrease in the amount of lignin due to the effect of salts. 
INTERNATIONAL JOURNAL OF

MULTIDISCIPLINARY STUDIES IN ARCHITECTURE

AND CULTURAL HERITAGE
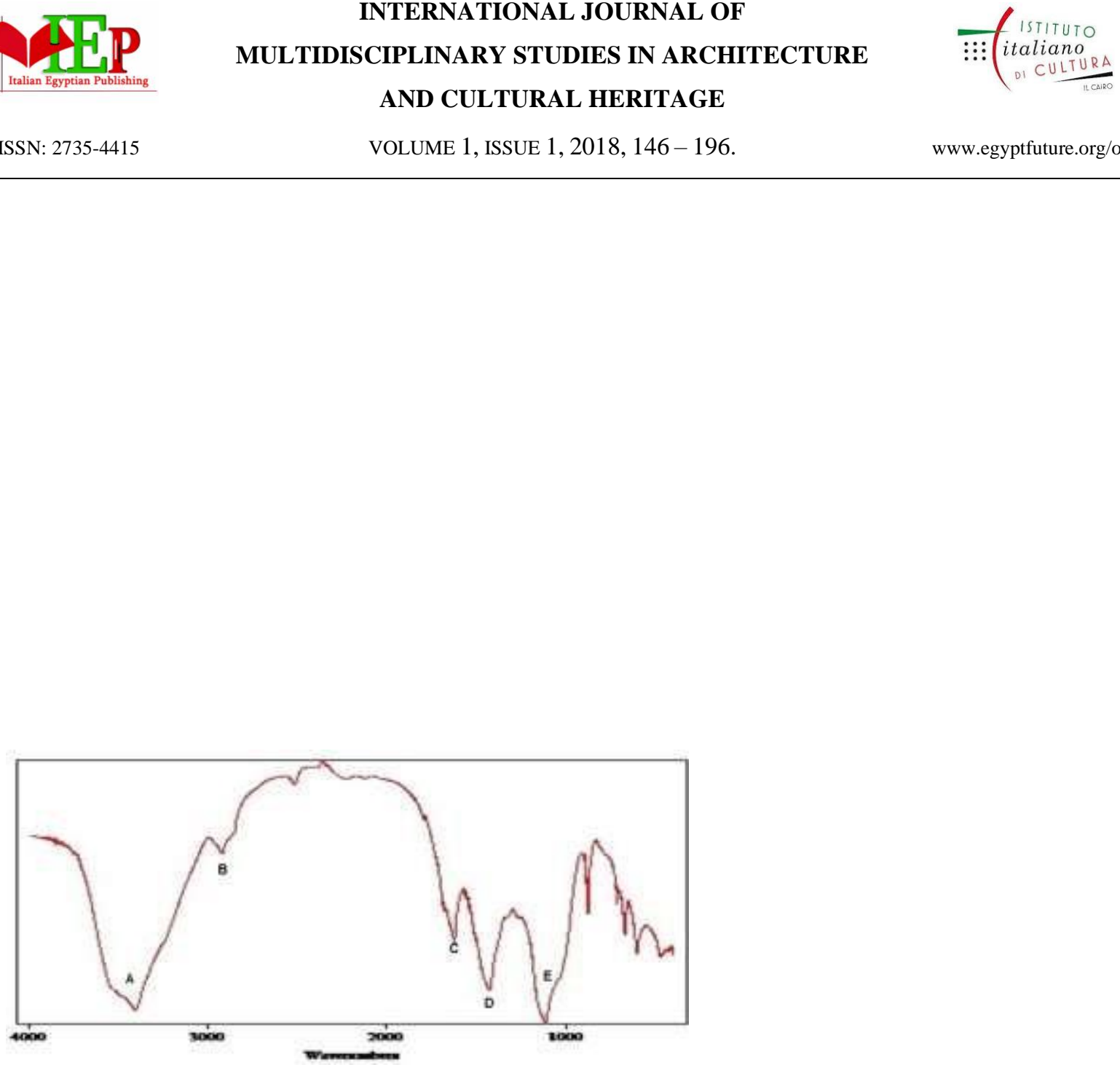

Figure 1-10 FTIR spectra for composite sample "lime and wood" form a window the first floor inQaitbay castle.

Table "4"The FTIR analysis results of wood sample. 


\begin{tabular}{ll|c}
\multicolumn{1}{c}{ Type } & \multicolumn{1}{c}{$\begin{array}{c}\text { Function } \\
\text { group }\end{array}$} & $\begin{array}{c}\text { Wavenumber to } \\
\text { sample }\end{array}$ \\
\hline A & Stretching $(\mathrm{OH})$ & $\mathbf{3 4 0 8}$ \\
\hline $\mathrm{B}$ & Stretching $(\mathrm{CH})$ & $\mathbf{2 9 2 4}$ \\
\hline $\mathrm{C}$ & $(\mathrm{H}-\mathrm{O}-\mathrm{H})$ Stretching & $\mathbf{1 6 2 4}$ \\
\hline $\mathrm{D}$ & $\mathrm{CO}_{3}$ Stretching & $\mathbf{1 3 1 1}$ \\
\hline $\mathrm{E}$ & $\mathrm{O}-\mathrm{C}-\mathrm{O}$ Bending & $\mathbf{8 9 9}$ \\
\hline
\end{tabular}




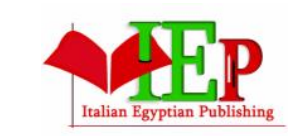

ISSN: $2735-4415$

\section{INTERNATIONAL JOURNAL OF \\ MULTIDISCIPLINARY STUDIES IN ARCHITECTURE AND CULTURAL HERITAGE}

VOLUME 1, ISSUE 1, 2018, 146 - 196.

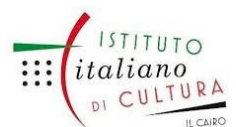

www.egyptfuture.org/ojs/

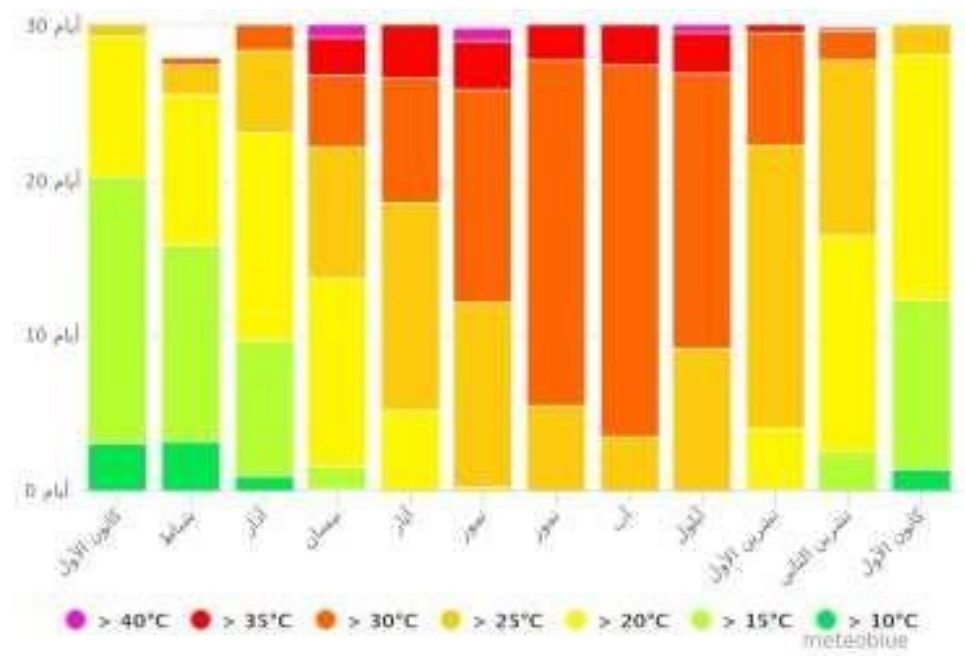

Figure 1-11 Records of temperature in Alexandria.

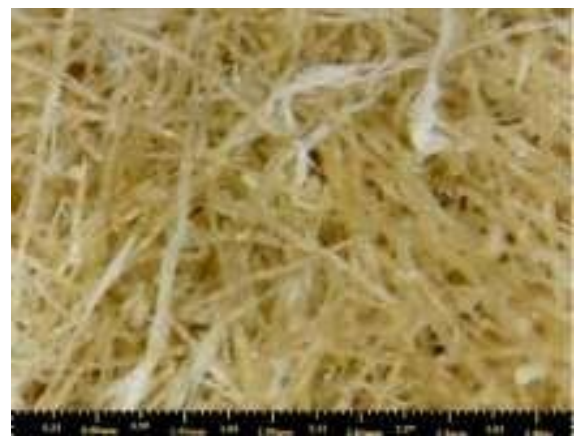


Figure (2-3) digital microscopeimage from Figure (2-1) shows that defiberation of cellulose fibers and crystallization of salts on the surfaceand penetration into the fibers.

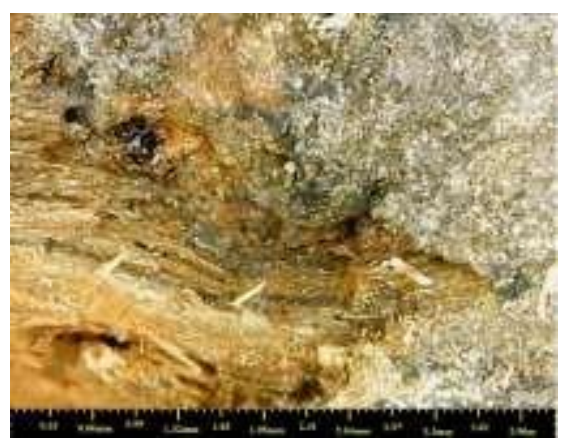

Figure (2-4) digital microscope image from Figure (2-2) shows that corrosion layer and accumulation of salts crystals inside the wood texture.

Digital microscope images shows that defiberation, it shows salts which covers the fiber surface as a layer, and the salts have an effect on lignin and hemicellulose more thancellulose. 


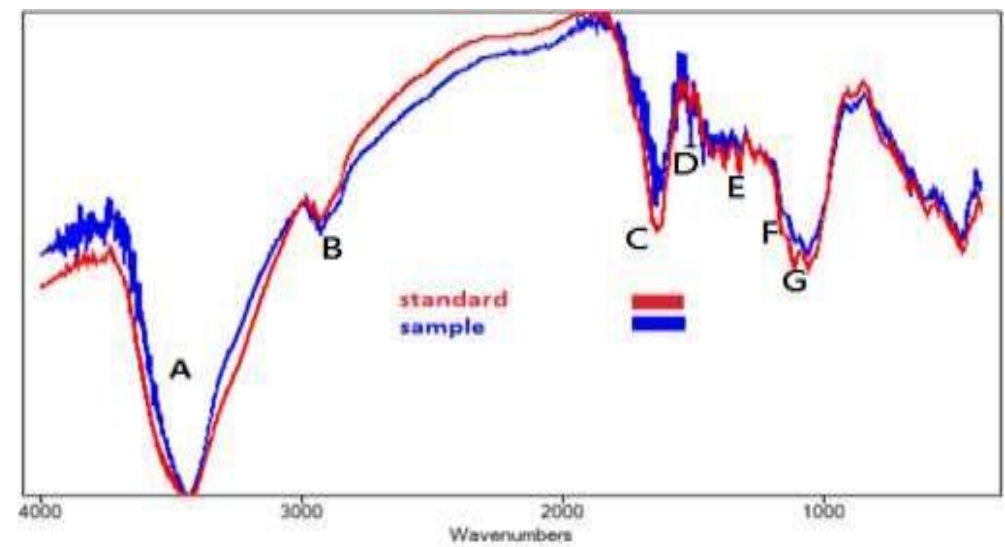

Fig.2-5 FTIR spectra for wooden surface from the AI-Manadili house.

Table "5"The FTIR analysis results of wood sample. 


\begin{tabular}{|c|c|c|c|c|c|}
\hline Type & $\begin{array}{l}\text { Function } \\
\text { group }\end{array}$ & $\begin{array}{l}\text { Wavenumb } \\
\text { erof } \\
\text { standard }\end{array}$ & $\begin{array}{l}\text { Wavenumb } \\
\text { erof } \\
\text { sample }\end{array}$ & $\begin{array}{l}\text { Assignmen } \\
\mathrm{t}\end{array}$ & $\begin{array}{l}\text { Note } \\
\mathrm{s}\end{array}$ \\
\hline A & Stretching $(\mathrm{OH})$ & $\begin{array}{l}342 \\
0\end{array}$ & $\begin{array}{l}342 \\
0\end{array}$ & Cellulose & $\begin{array}{l}\text { Increase in } \\
\text { board }\end{array}$ \\
\hline$B$ & Stretching $(\mathrm{CH})$ & $\begin{array}{l}292 \\
5\end{array}$ & $\begin{array}{l}291 \\
1\end{array}$ & Cellulose & $\begin{array}{l}\text { Increase in } \\
\text { intensity } \\
\text { and } \\
\text { board }\end{array}$ \\
\hline C & $\begin{array}{l}\text { Stretching }(\mathrm{C}=\mathrm{O}) \\
\text { conjugated }\end{array}$ & $\begin{array}{l}173 \\
5\end{array}$ & $\begin{array}{l}173 \\
5\end{array}$ & Hemicellulose & $\begin{array}{r}\text { Hemicellulose } \\
\text { disappeared }\end{array}$ \\
\hline D & $\begin{array}{l}\text { Stretching }(\mathrm{C}=\mathrm{O}) \\
\text { unconjugated }\end{array}$ & $\begin{array}{l}165 \\
4\end{array}$ & $\begin{array}{l}165 \\
4\end{array}$ & $\begin{array}{l}\text { Cellulose } \\
\text { oxidation }\end{array}$ & $\begin{array}{l}\text { Increase in } \\
\text { intensity }\end{array}$ \\
\hline$E$ & Stretching $(\mathrm{C}=\mathrm{C})$ & $\begin{array}{l}151 \\
4\end{array}$ & $\begin{array}{l}151 \\
0\end{array}$ & Lignin & Little change \\
\hline$F$ & Bending $(\mathrm{CH})$ & $\begin{array}{l}142 \\
1\end{array}$ & $\begin{array}{l}142 \\
5\end{array}$ & $\begin{array}{l}\text { Cellulose } \\
\text { crystallinity }\end{array}$ & $\begin{array}{l}\text { Increase in } \\
\text { intensity }\end{array}$ \\
\hline $\mathrm{G}$ & $\begin{array}{l}\text { Stretching }(\mathrm{C}-\mathrm{O}- \\
\mathrm{C})\end{array}$ & $\begin{array}{l}115 \\
2\end{array}$ & $\begin{array}{l}115 \\
9\end{array}$ & $\begin{array}{l}\text { Cellulose } \\
\text { polymerizatio } \\
n\end{array}$ & $\begin{array}{l}\text { Little Increase } \\
\text { in } \\
\text { intensity }\end{array}$ \\
\hline
\end{tabular}

Fig 2-5 FTIR spectra shows that Increase in board in $(\mathrm{OH})$ stretching at $3420 \mathrm{~cm}^{-1}$ and change in intensity in (C-O-C) stretcghing at $1152 \mathrm{~cm}^{-1}$ in cellulose polymerization indicates an increase in humidity, because the hydrolysis caused by moisture leads to a breaking in cellulose polymerization. 


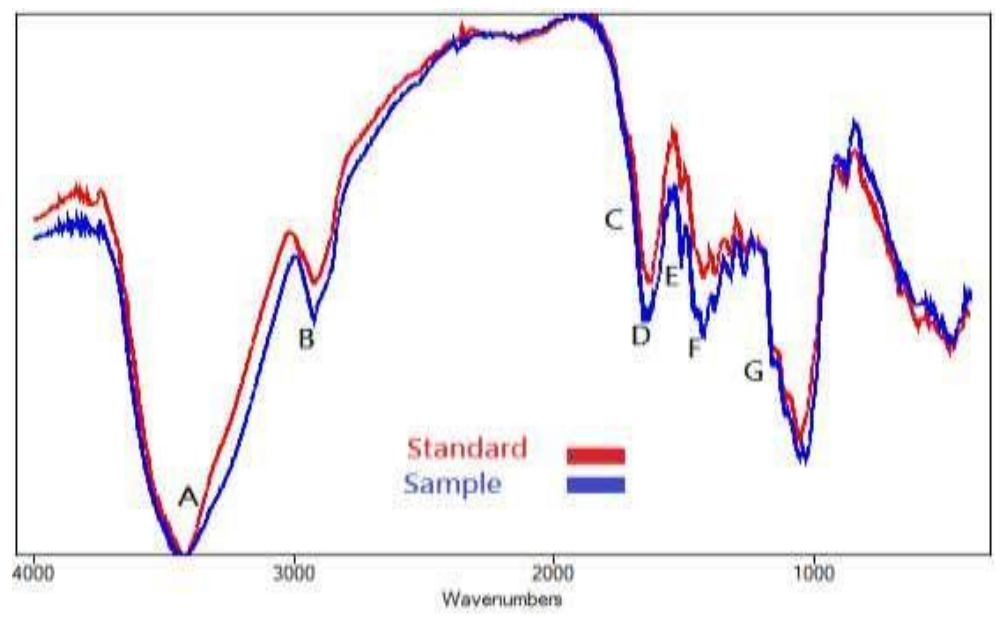

Fig.2-6 FTIR spectra for wooden surface from an Azouz bath.

Table "6"The FTIR analysis results of wood sample.

\begin{tabular}{|l|l|c|c|c|c|}
\hline Type & $\begin{array}{l}\text { Function } \\
\text { group }\end{array}$ & $\begin{array}{l}\text { Wavenumb } \\
\text { erof } \\
\text { standard }\end{array}$ & $\begin{array}{c}\text { Wavenumb } \\
\text { erof } \\
\text { sample }\end{array}$ & $\begin{array}{c}\text { Assignmen } \\
\mathrm{t}\end{array}$ & Notes \\
\hline A & Stretching $(\mathrm{OH})$ & $\begin{array}{l}343 \\
0\end{array}$ & $\begin{array}{l}343 \\
0\end{array}$ & Cellulose & $\begin{array}{l}\text { Increase } \\
\text { in board }\end{array}$ \\
\hline
\end{tabular}




\begin{tabular}{|c|c|c|c|c|c|}
\hline B & Stretching $(\mathrm{CH})$ & $\begin{array}{l}292 \\
6\end{array}$ & $\begin{array}{l}292 \\
6\end{array}$ & Cellulose & $\begin{array}{l}\text { No } \\
\text { change }\end{array}$ \\
\hline C & $\begin{array}{c}\text { Stretching }(\mathrm{C}=\mathrm{O}) \text { and } \\
(\mathrm{H}-\mathrm{O}-\mathrm{H})\end{array}$ & $\begin{array}{l}164 \\
0\end{array}$ & $\begin{array}{l}164 \\
0\end{array}$ & $\begin{array}{l}\text { Cellulose } \\
\text { Oxidation }\end{array}$ & $\begin{array}{l}\text { Decreas } \\
\text { ein } \\
\text { intensity }\end{array}$ \\
\hline D & Stretching $(C=C)$ & $\begin{array}{l}151 \\
0\end{array}$ & $\begin{array}{l}151 \\
0\end{array}$ & Lignin & $\begin{array}{l}\text { No } \\
\text { change }\end{array}$ \\
\hline $\mathrm{E}$ & Bending $(\mathrm{CH})$ & $\begin{array}{l}142 \\
7\end{array}$ & $\begin{array}{l}142 \\
7\end{array}$ & $\begin{array}{l}\text { Cellulose } \\
\text { crystallinity }\end{array}$ & $\begin{array}{l}\text { No } \\
\text { change }\end{array}$ \\
\hline $\mathrm{F}$ & $\begin{array}{l}\text { Stretching (C-O- } \\
\text { C) }\end{array}$ & $\begin{array}{l}115 \\
3\end{array}$ & $\begin{array}{l}115 \\
3\end{array}$ & $\begin{array}{l}\text { Cellulose } \\
\text { polymerization }\end{array}$ & $\begin{array}{l}\text { No } \\
\text { change }\end{array}$ \\
\hline G & Stretching (C-O) & $\begin{array}{l}108 \\
2\end{array}$ & $\begin{array}{l}108 \\
2\end{array}$ & $\begin{array}{l}\text { Cellulose, Lignin } \\
\text { and } \\
\text { Hemicellulose }\end{array}$ & $\begin{array}{l}\text { increas } \\
\text { e } \\
\text { in } \\
\text { intensit } \\
y\end{array}$ \\
\hline
\end{tabular}

Fig 2-6 FTIR spectra shows that little increase in board in $(\mathrm{OH})$ stretching at $3430 \mathrm{~cm}^{-1}$ due toan increase in water content resulting from the beginning of a simple hydrolysis. 


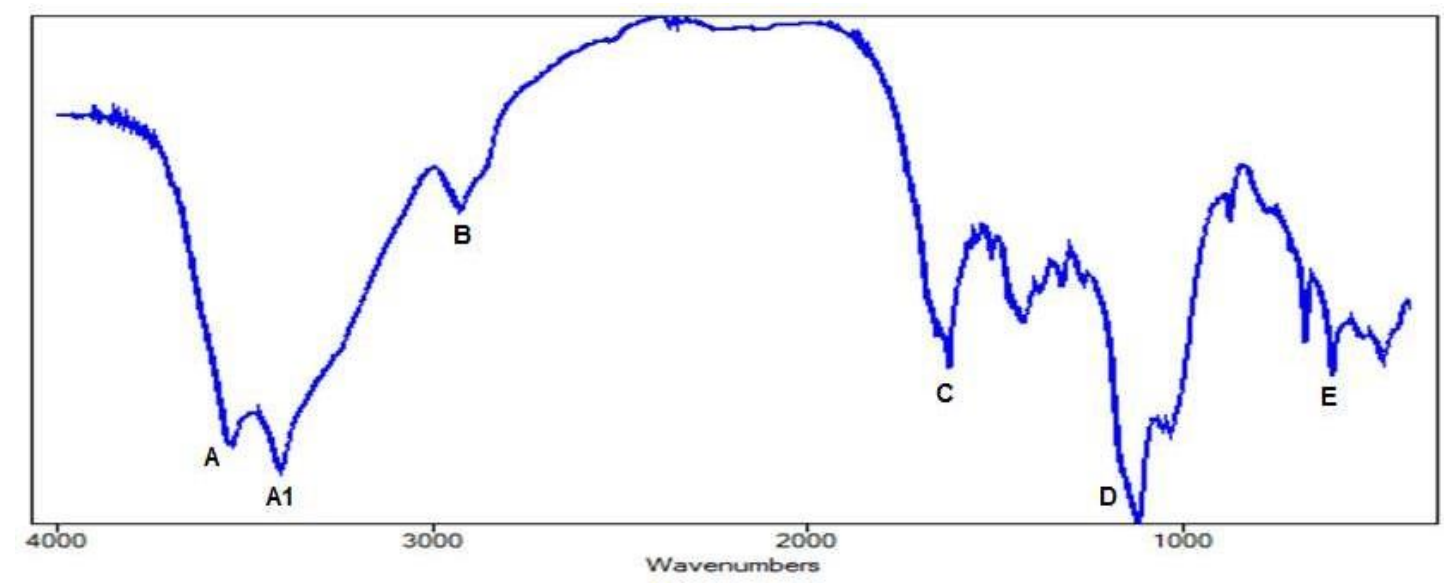

Figure 2-7. FTIR spectra for composite sample "gypsum and wood" form wooden beam in Manadilihouse.

Table "7"The FTIR analysis results of wood sample. 
INTERNATIONAL JOURNAL OF

MULTIDISCIPLINARY STUDIES IN ARCHITECTURE AND CULTURAL HERITAGE

\begin{tabular}{l|l|c|}
\multicolumn{1}{c}{ Type } & \multicolumn{1}{c}{$\begin{array}{c}\text { Function } \\
\text { group }\end{array}$} & $\begin{array}{c}\text { Wavenumber to } \\
\text { sample }\end{array}$ \\
\hline A & Asymmetric and Anti symmetric & $3546-$ \\
& Stretching $(\mathrm{OH})$ & 3406 \\
\hline $\mathrm{B}$ & Stretching $(\mathrm{CH})$ & $\mathbf{2 9 2 4}$ \\
\hline $\mathrm{C}$ & Stretching(H-O-H) & $\mathbf{1 6 2 4}$ \\
\hline $\mathrm{D}$ & Asymmetric $\mathrm{SO}_{4}$ Stretching & $\mathbf{1 1 1 8}$ \\
\hline $\mathrm{E}$ & $\mathrm{SO}_{4}$ Bending & $\mathbf{6 0 3}$ \\
\hline
\end{tabular}

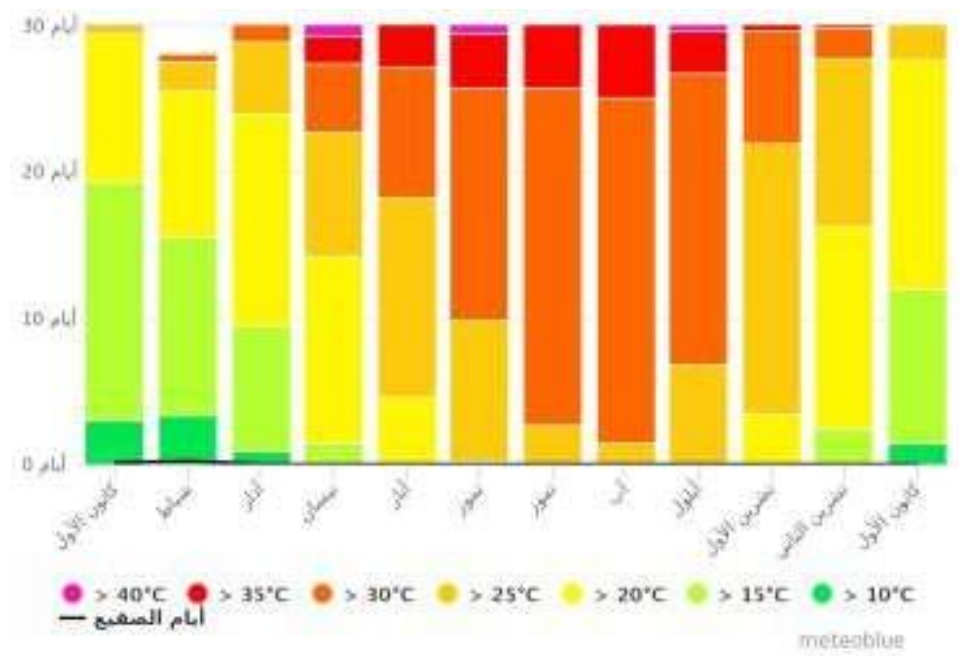

Figure 2-8 Records of temperature in Rashid. 


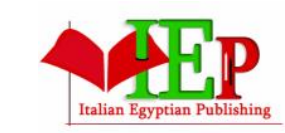

ISSN: $2735-4415$

\section{INTERNATIONAL JOURNAL OF \\ MULTIDISCIPLINARY STUDIES IN ARCHITECTURE \\ AND CULTURAL HERITAGE}

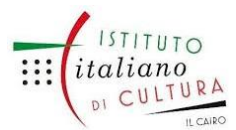

www.egyptfuture.org/ojs/

Central Egypt

Cairo "Ahmed Ibn Tulun Mosque, Rifai Mosque and Mosque and school of Sultan Nasser Hassan"

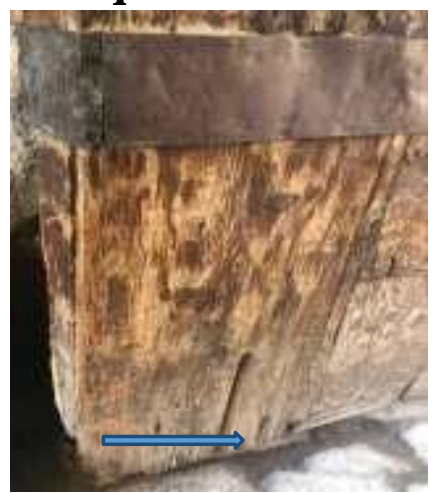

Figure (3-1) from a door in

Ahmed Ibn Toulon shows that the wood

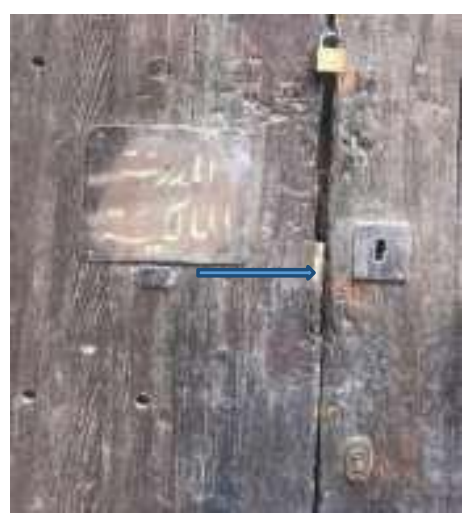


Figure (3-2) from a door inElsoltan Hassan school shows that the wood suffer from height humidity, biologic deterioration and defiberation.

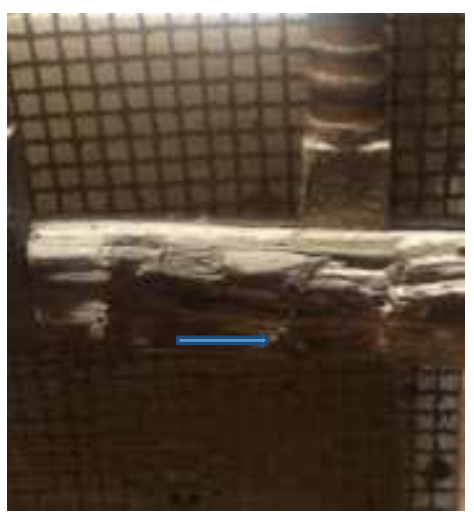

Figure (3-3) from a door in Ahmed Ibn Toulon mosqueshows that the wood suffer from defiberation and biological deterioration.

These figures shows that defiberation and biological deterioration such as (some tunnels andholes) as a result to highly humidity. 


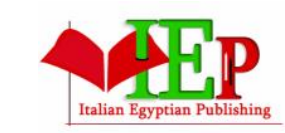

ISSN: $2735-4415$

\section{INTERNATIONAL JOURNAL OF \\ MULTIDISCIPLINARY STUDIES IN ARCHITECTURE AND CULTURAL HERITAGE}

VOLUME 1, ISSUE 1, 2018, 146 - 196.

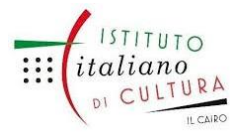

www.egyptfuture.org/ojs/

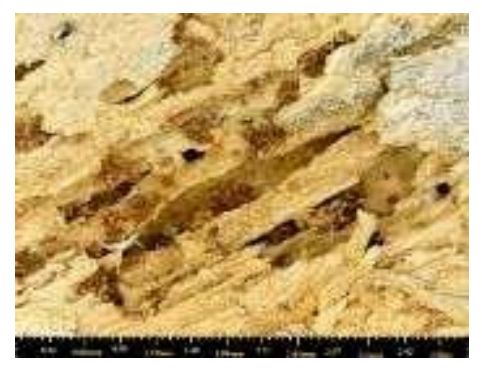

Figure (3-4) digital microscope image fromFigure (3-1) shows that biological deterioration (holes, tunnels) and defiberation.

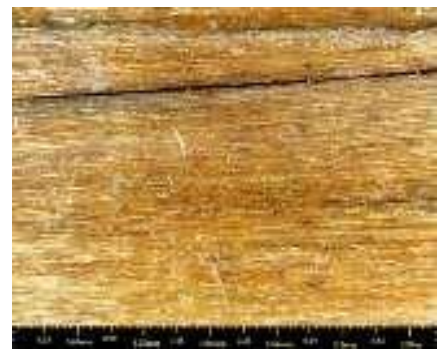

Figure (3-5) from Figure digital microscope image (3-2) shows that cracks there is biological deterioration (holes, tunnelsand different colors). 


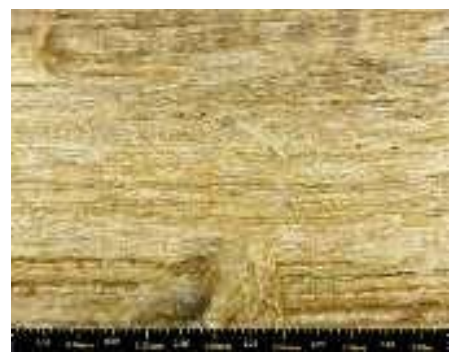

Figure (3-6) digital microscope image Figure (3-3) shows that defiberation andbiological deterioration.

Digital microscope images shows that some different colors like (deep black, white andblack) because of covering the wood with a layer of resin and humidity. 


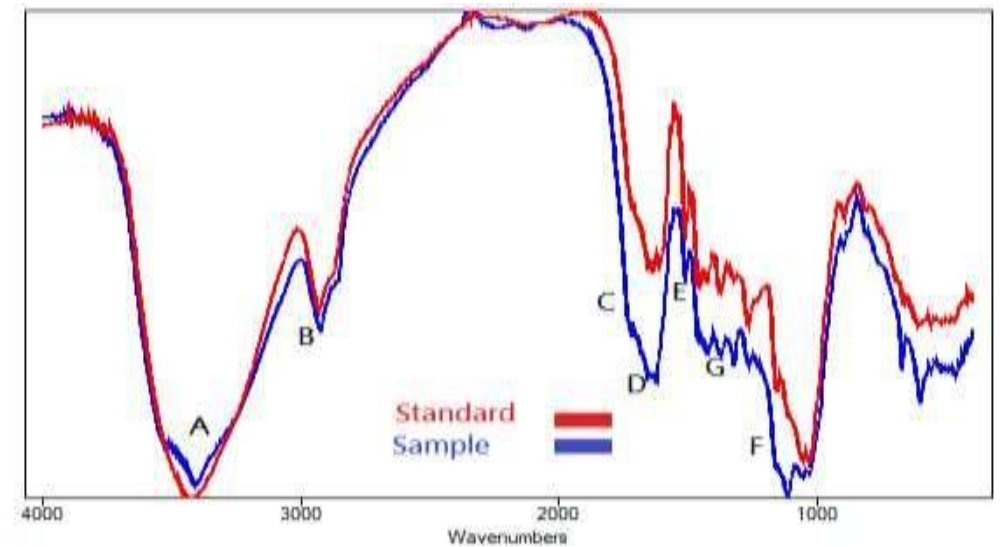

Fig.3-7 FTIR spectra for wooden surface from door in Ahmed Ibn Toulon mosque

Table "8"The FTIR analysis results of wood sample.

\begin{tabular}{|c|c|c|c|c|c|}
\hline Type & $\begin{array}{l}\text { Functio group } \\
\mathrm{n}\end{array}$ & $\begin{array}{l}\text { Wavenumb } \\
\text { erto } \\
\text { standard }\end{array}$ & $\begin{array}{l}\text { Wavenumb } \\
\text { erto } \\
\text { sample }\end{array}$ & $\begin{array}{l}\text { The } \\
\text { place }\end{array}$ & $\begin{array}{l}\text { Note } \\
\mathrm{s}\end{array}$ \\
\hline$A$ & Stretching $(\mathrm{OH})$ & $\begin{array}{l}341 \\
8\end{array}$ & $\begin{array}{l}340 \\
4\end{array}$ & Cellulose & $\begin{array}{l}\text { No } \\
\text { change }\end{array}$ \\
\hline$B$ & Stretching $(\mathrm{CH})$ & $\begin{array}{l}293 \\
5\end{array}$ & $\begin{array}{l}292 \\
5\end{array}$ & Cellulose & $\begin{array}{l}\text { No } \\
\text { change }\end{array}$ \\
\hline
\end{tabular}




\begin{tabular}{|l|l|l|l|l|l|}
\hline C & $\begin{array}{l}\text { Stretching }(\mathrm{C}= \\
\text { O) } \\
\text { conjugated }\end{array}$ & $\begin{array}{l}173 \\
5\end{array}$ & $\begin{array}{l}173 \\
5\end{array}$ & Hemicellulose & $\begin{array}{l}\text { increas } \\
\text { in } \\
\text { in } \\
\text { intensit } \\
y\end{array}$ \\
\hline D & $\begin{array}{l}\text { Stretching(C= } \\
\text { O) } \\
\text { Unconjugated }\end{array}$ & $\begin{array}{l}165 \\
\text { E }\end{array}$ & $\begin{array}{l}\text { 165 } \\
4\end{array}$ & Cellulose Oxidation & $\begin{array}{l}\text { No } \\
\text { change }\end{array}$ \\
\hline E & Stretching(C=C) & 150 & 150 & Lignin & $\begin{array}{l}\text { No } \\
\text { change }\end{array}$ \\
\hline G & Bending (CH) & $\begin{array}{l}7 \\
7\end{array}$ & $\begin{array}{l}142 \\
5\end{array}$ & $\begin{array}{l}\text { Cellulose } \\
\text { crystallinity }\end{array}$ & $\begin{array}{l}\text { No } \\
\text { change }\end{array}$ \\
\hline F & Stretching (C-O-C) & 115 & 115 & Cellulose & $\begin{array}{l}\text { Increas } \\
\text { e }\end{array}$ \\
\hline
\end{tabular}

Fig 3-7 FTIR spectra shows that change in intensity in Stretching $(C=O)$ conjugated (1654) and little Increase in intensity in Cellulose polymerization) C-O-C) Stretching at (1158) refer to climatic fluctuations. 


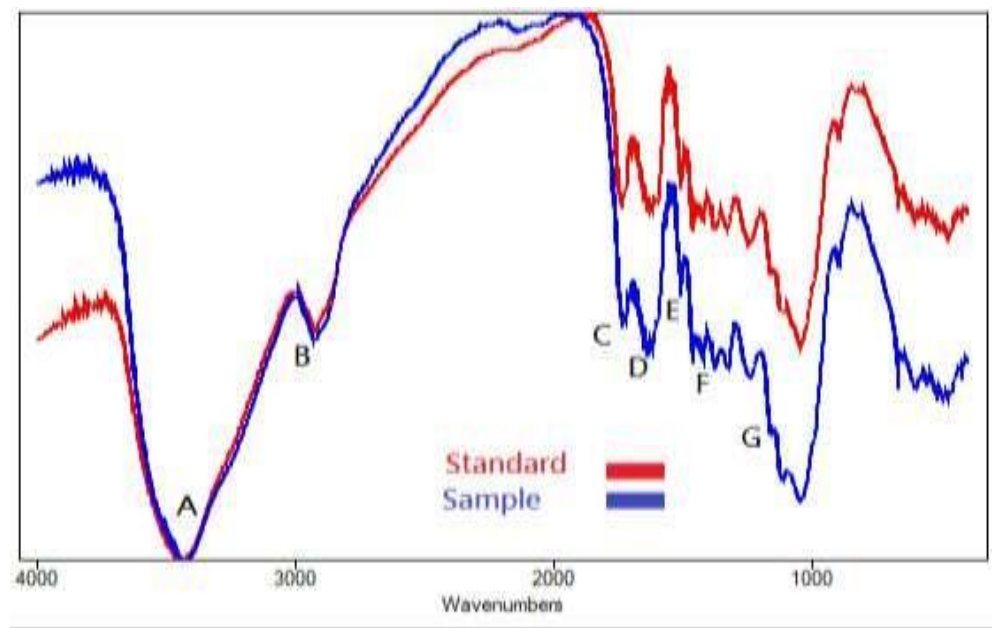

Fig.3-8 FTIR spectra for wooden surface from a door in Elsoltan Hassan School

Table "9"The FTIR analysis results of wood sample. 
INTERNATIONAL JOURNAL OF

MULTIDISCIPLINARY STUDIES IN ARCHITECTURE

AND CULTURAL HERITAGE

\begin{tabular}{|c|c|c|c|c|c|}
\hline Type & $\begin{array}{l}\text { Function } \\
\text { group }\end{array}$ & $\begin{array}{l}\text { Wavenumb } \\
\text { erto } \\
\text { standard }\end{array}$ & $\begin{array}{l}\text { Wavenumb } \\
\text { erto } \\
\text { sample }\end{array}$ & $\begin{array}{l}\text { The } \\
\text { place }\end{array}$ & Notes \\
\hline A & Stretching $(\mathrm{OH})$ & $\begin{array}{l}342 \\
8\end{array}$ & $\begin{array}{l}342 \\
8\end{array}$ & Cellulose & $\begin{array}{l}\text { No } \\
\text { chang } \\
\text { e }\end{array}$ \\
\hline B & Stretching $(\mathrm{CH})$ & $\begin{array}{l}292 \\
8\end{array}$ & $\begin{array}{l}292 \\
8\end{array}$ & Cellulose & $\begin{array}{l}\text { No } \\
\text { chang } \\
\text { e }\end{array}$ \\
\hline C & $\begin{array}{l}\text { Stretching }(\mathrm{C}=\mathrm{O}) \\
\text { Conjugated }\end{array}$ & $\begin{array}{l}173 \\
8\end{array}$ & $\begin{array}{l}173 \\
8\end{array}$ & Hemicellulose & $\begin{array}{l}\text { No } \\
\text { chang } \\
\text { e }\end{array}$ \\
\hline D & $\begin{array}{l}\text { Stretching }(C=O) \text { Unconjugat } \\
\text { ed }\end{array}$ & $\begin{array}{l}165 \\
0\end{array}$ & $\begin{array}{l}165 \\
0\end{array}$ & $\begin{array}{l}\text { Cellulose } \\
\text { Oxidation }\end{array}$ & $\begin{array}{l}\text { No } \\
\text { chang } \\
\mathrm{e}\end{array}$ \\
\hline$E$ & Stretching $(C=C)$ & $\begin{array}{l}150 \\
8\end{array}$ & $\begin{array}{l}150 \\
8\end{array}$ & Lignin & $\begin{array}{l}\text { No } \\
\text { chang } \\
\text { e }\end{array}$ \\
\hline $\mathrm{F}$ & Bending $(\mathrm{CH})$ & $\begin{array}{l}142 \\
5\end{array}$ & $\begin{array}{l}142 \\
3\end{array}$ & $\begin{array}{l}\text { Cellulose } \\
\text { crystanility }\end{array}$ & $\begin{array}{l}\text { No } \\
\text { chang } \\
\text { e }\end{array}$ \\
\hline G & Stretching (C-O-C) & $\begin{array}{l}115 \\
9\end{array}$ & $\begin{array}{l}115 \\
9\end{array}$ & $\begin{array}{l}\text { Cellulose } \\
\text { polymerizatio } \\
\text { n }\end{array}$ & $\begin{array}{l}\text { No } \\
\text { chang } \\
\text { e }\end{array}$ \\
\hline
\end{tabular}

Fig 3-8FTIR spectra shows that not change in chemical composition because the sample weretaken from indoor in the school and there is far of temperature and humidity. 
INTERNATIONAL JOURNAL OF

MULTIDISCIPLINARY STUDIES IN ARCHITECTURE AND CULTURAL HERITAGE

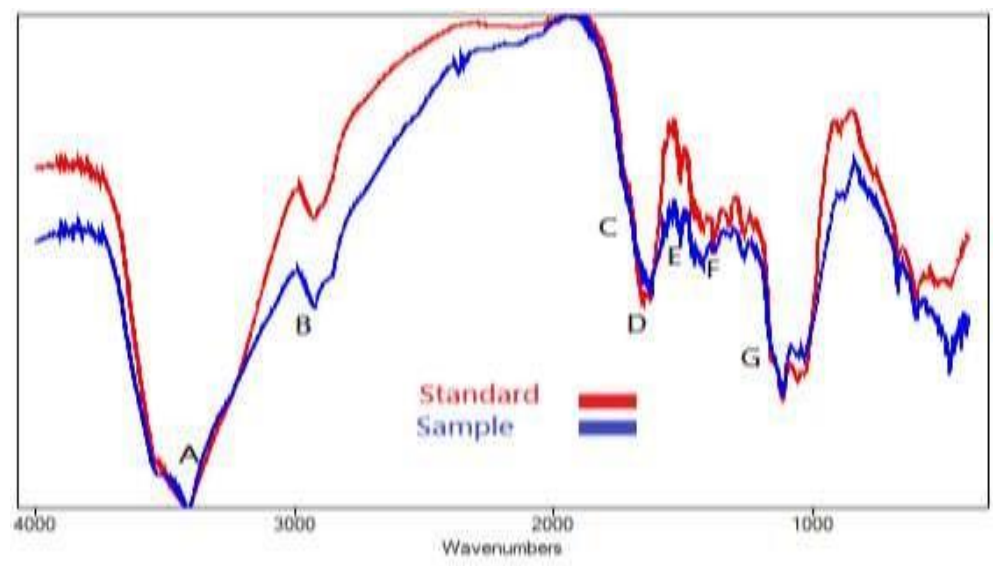

Fig.3-9 FTIR spectra for wooden surface from a door in Elrefaee mosque

Table "10"The FTIR analysis results of wood sample. 
INTERNATIONAL JOURNAL OF

MULTIDISCIPLINARY STUDIES IN ARCHITECTURE

AND CULTURAL HERITAGE

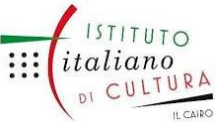

\begin{tabular}{|c|c|c|c|c|c|}
\hline Type & $\begin{array}{l}\text { Function } \\
\text { group }\end{array}$ & $\begin{array}{l}\text { Wavenumb } \\
\text { erto } \\
\text { standard }\end{array}$ & $\begin{array}{l}\text { Wavenumb } \\
\text { erto } \\
\text { sample }\end{array}$ & $\begin{array}{l}\text { The } \\
\text { place }\end{array}$ & Notes \\
\hline$A$ & Stretching $(\mathrm{OH})$ & $\begin{array}{l}340 \\
4\end{array}$ & $\begin{array}{l}340 \\
4\end{array}$ & Cellulose & $\begin{array}{l}\text { Little } \\
\text { Increase in } \\
\text { board }\end{array}$ \\
\hline$B$ & Stretching $(\mathrm{CH})$ & $\begin{array}{l}292 \\
5\end{array}$ & $\begin{array}{l}292 \\
5\end{array}$ & Cellulose & $\begin{array}{l}\text { Increase } \\
\text { inboard } \\
\text { and }\end{array}$ \\
\hline
\end{tabular}




\begin{tabular}{|c|c|c|c|c|c|}
\hline & & & & & intensity \\
\hline C & $\begin{array}{l}\text { Stretching }(\mathrm{C}=\mathrm{O}) \\
\text { Conjugated }\end{array}$ & $\begin{array}{l}173 \\
5\end{array}$ & $\begin{array}{l}173 \\
5\end{array}$ & Hemicellulose & No change \\
\hline D & $\begin{array}{l}\text { Stretching }(\mathrm{C}=\mathrm{O}) \\
\text { Unconjugated }\end{array}$ & $\begin{array}{l}165 \\
8\end{array}$ & $\begin{array}{l}165 \\
8\end{array}$ & $\begin{array}{l}\text { Cellulose } \\
\text { Oxidation }\end{array}$ & No change \\
\hline$E$ & Stretching $(C=C)$ & $\begin{array}{l}151 \\
0\end{array}$ & $\begin{array}{l}150 \\
9\end{array}$ & Lignin & $\begin{array}{l}\text { Decrease } \\
\text { in } \\
\text { intensity }\end{array}$ \\
\hline $\mathrm{F}$ & Bending $(\mathrm{CH})$ & $\begin{array}{l}142 \\
5\end{array}$ & $\begin{array}{l}142 \\
3\end{array}$ & $\begin{array}{l}\text { Cellulose } \\
\text { crystallinity }\end{array}$ & No change \\
\hline G & $\begin{array}{l}\text { Stretching (C-O- } \\
\text { C) }\end{array}$ & $\begin{array}{l}116 \\
1\end{array}$ & $\begin{array}{l}116 \\
1\end{array}$ & $\begin{array}{l}\text { Cellulose } \\
\text { polymerizatio } \\
\mathrm{n}\end{array}$ & No change \\
\hline
\end{tabular}

Fig 3-9FTIR spectra shows that Little Increase in board in $(\mathrm{OH})$ stretching at $3404 \mathrm{~cm}^{-1}$ and Increase in intensity and board $(\mathrm{CH})$ stretching at 2925 $\mathrm{cm}^{-1}$ refer to high humidity as a result to taking from an area next to bathroom and little decrease in intensity $(C=C)$ stretching at $1510 \mathrm{~cm}^{-1}$ indicates a decrease in the rate of Lignin due to the effect of salts. 


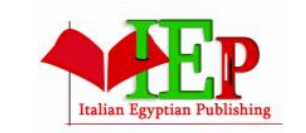

ISSN: 2735-4415

\section{INTERNATIONAL JOURNAL OF \\ MULTIDISCIPLINARY STUDIES IN ARCHITECTURE \\ AND CULTURAL HERITAGE}

VOLUME 1, ISSUE 1, 2018, 146 - 196.

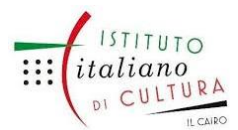

www.egyptfuture.org/ojs/

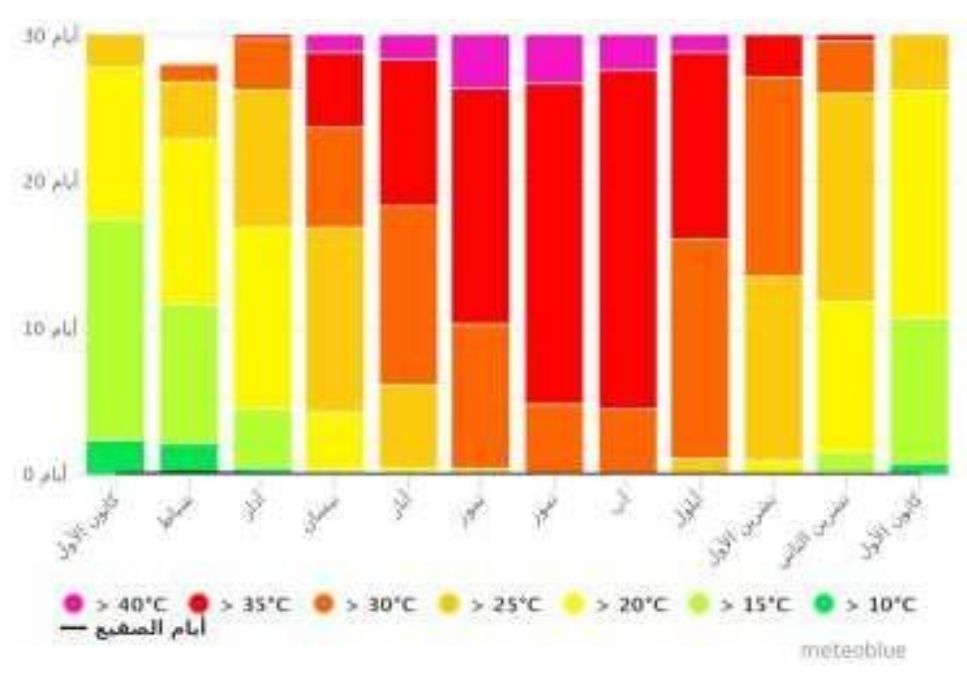

Figure 3-10 Records of temperature in Cairo.

Upper Egypt Qena "Qus city" 


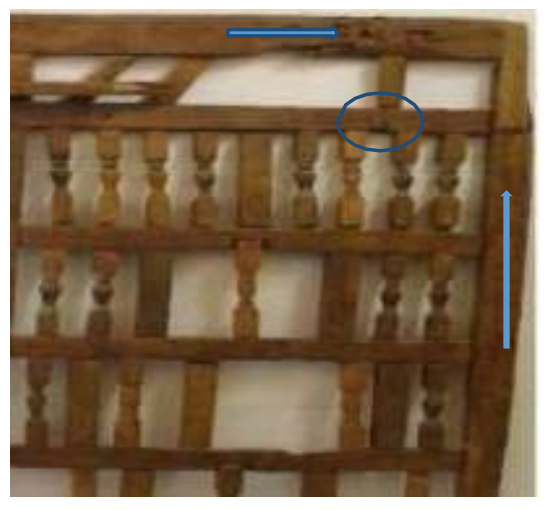

Figure (4-1) The front facade of the wooden compartment at the OmariMosque in the city of Qus.

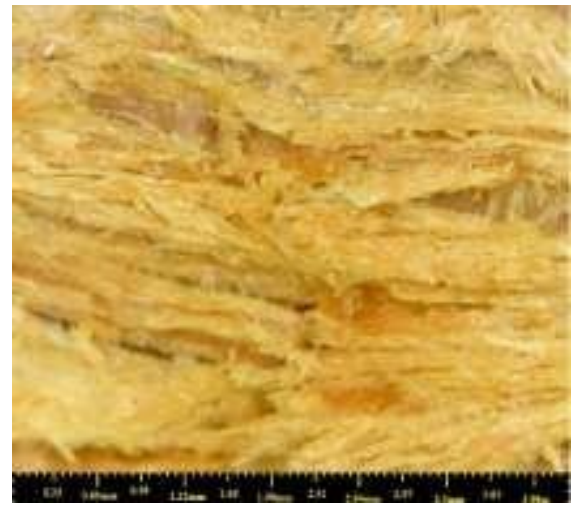

Figure (4-2) digital microscope Figure from figure (4-1) shows that breaking, secessions, castrate in the fiber as a result to temperature.

The figure (4-1) shows the superficial deterioration, which includes the 
flakes in the surfaceand the fractures in wooden column, missing parts, biological damage, distress ions, corrosion, splitting and the presence of a layer of glue on the wooden units.

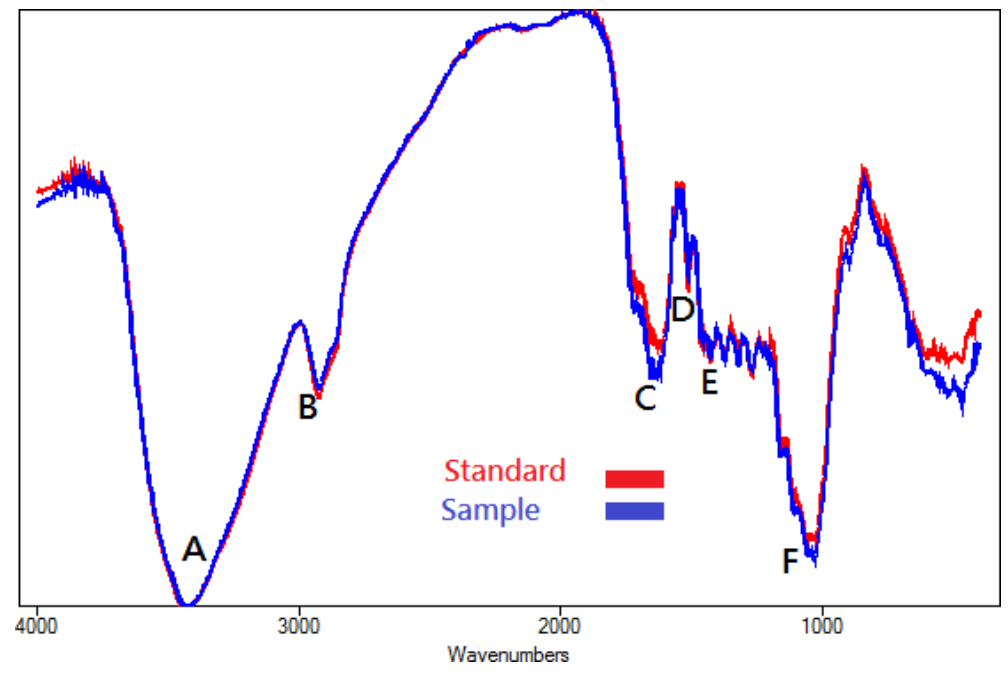

Fig.4-3FTIR spectra for wooden surface from wooden compartment at the Omari Mosque 


\begin{tabular}{|c|c|c|c|c|c|}
\hline Type & $\begin{array}{l}\text { Function } \\
\text { group }\end{array}$ & $\begin{array}{l}\text { Wavenumb } \\
\text { erto } \\
\text { standard }\end{array}$ & $\begin{array}{l}\text { Wavenumb } \\
\text { erto } \\
\text { sample }\end{array}$ & $\begin{array}{l}\text { The } \\
\text { place }\end{array}$ & $\begin{array}{l}\text { Note } \\
\mathrm{s}\end{array}$ \\
\hline A & Stretching $(\mathrm{OH})$ & $\begin{array}{l}342 \\
3\end{array}$ & $\begin{array}{l}342 \\
3\end{array}$ & Cellulose & $\begin{array}{l}\text { No } \\
\text { change }\end{array}$ \\
\hline B & $\begin{array}{l}\text { Stretching(C- } \\
\mathrm{H})\end{array}$ & $\begin{array}{l}292 \\
5\end{array}$ & $\begin{array}{l}292 \\
5\end{array}$ & cellulose & $\begin{array}{l}\text { No } \\
\text { change }\end{array}$ \\
\hline C & $\begin{array}{l}\text { unconjugated } \\
\text { Stretching } \\
(\mathrm{C}=\mathrm{O})\end{array}$ & $\begin{array}{l}173 \\
1\end{array}$ & $\begin{array}{l}173 \\
1\end{array}$ & Hemicellulose & $\begin{array}{l}\text { Little } \\
\text { Increase in } \\
\text { intensity }\end{array}$ \\
\hline $\mathrm{D}$ & $\begin{array}{l}\text { Stretching }(\mathrm{C}= \\
\mathrm{C})\end{array}$ & $\begin{array}{l}151 \\
4\end{array}$ & $\begin{array}{l}151 \\
4\end{array}$ & Lignin & $\begin{array}{l}\text { No } \\
\text { change }\end{array}$ \\
\hline$E$ & Bending $(\mathrm{CH})$ & $\begin{array}{l}142 \\
3\end{array}$ & $\begin{array}{l}142 \\
3\end{array}$ & $\begin{array}{l}\text { Cellulose } \\
\text { crystallinity }\end{array}$ & $\begin{array}{l}\text { No } \\
\text { change }\end{array}$ \\
\hline $\mathrm{F}$ & $\begin{array}{l}\text { Stretching } \\
(\mathrm{C}-\mathrm{O}-\mathrm{C})\end{array}$ & $\begin{array}{l}110 \\
9\end{array}$ & $\begin{array}{l}110 \\
9\end{array}$ & $\begin{array}{l}\text { Cellulose } \\
\text { polymerizatio } \\
\mathrm{n}\end{array}$ & $\begin{array}{l}\text { No } \\
\text { change }\end{array}$ \\
\hline
\end{tabular}

Table "11"The FTIR analysis results of wood sample.

Fig 4-3 FTIR spectra shows a slight increase in intensity in $(\mathrm{C}=\mathrm{O})$ stretching due to hightemperature in Upper Egypt. 


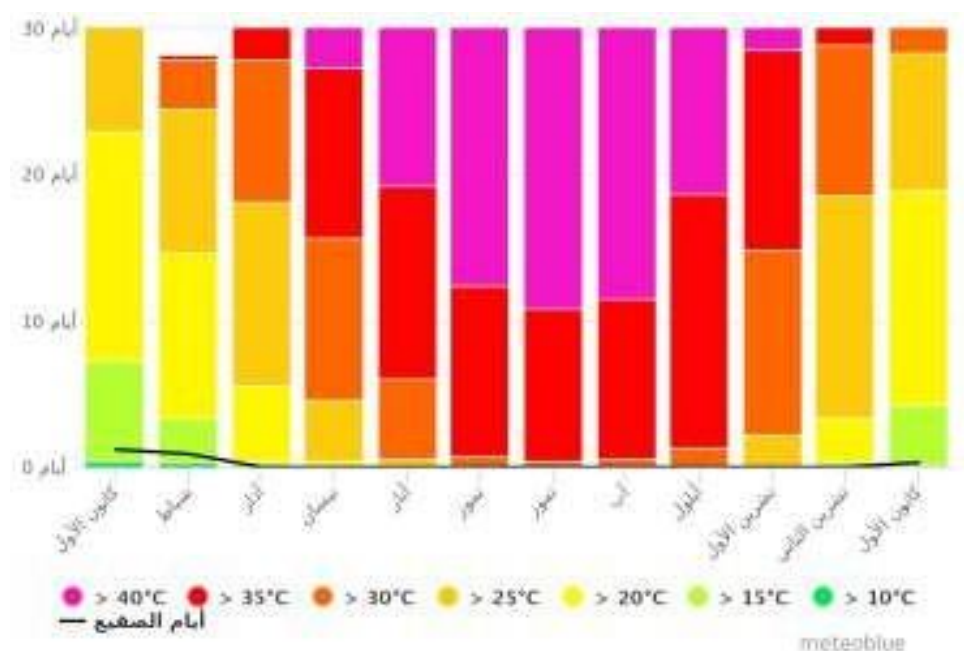

Figure 4-4 Records of temperature in Qus.

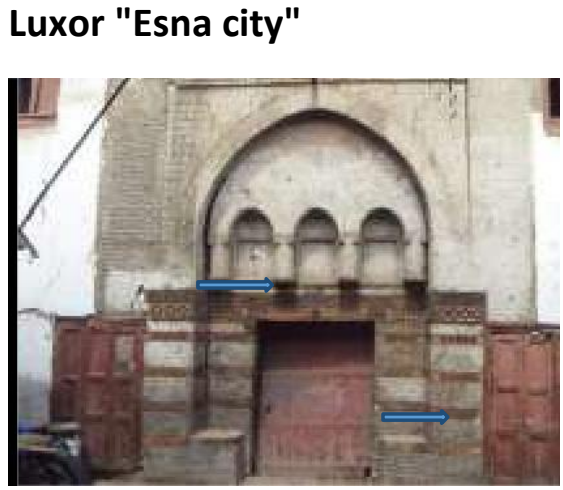


Figure (5-1) The main facade of the Jaddawi Agency shows the overlap of wood "wooden beams" with the building materials such as brick masonry, black cement, and mortarlayer of lime, in addition to mud bricks.

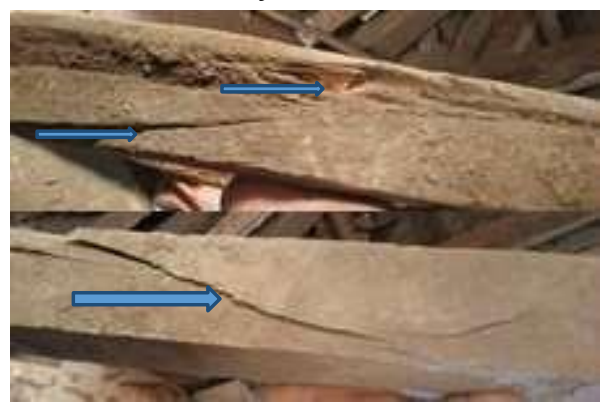

Figure (5-2) The wooden beams from

the ceiling have mud brick residues and suffer from loss in some parts, cracks, breakings, horizontal shear, and compression and cross grain tension. 
These figures shows damage found in the Jaddawi Agency in Esna due to environmentalconditions, compression and loads on wooden beams.

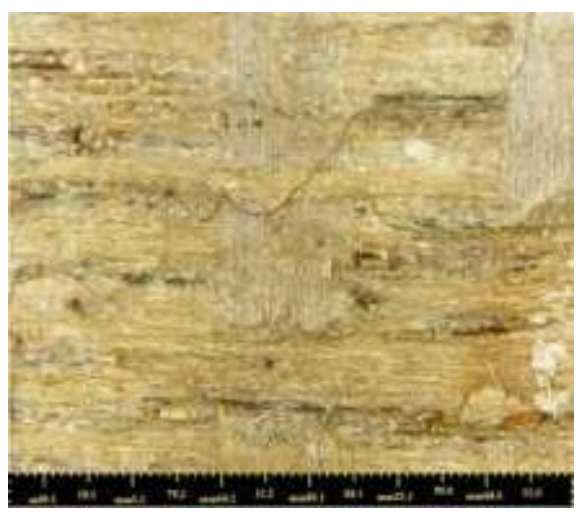

Figure (5-3) digital microscope Figure 


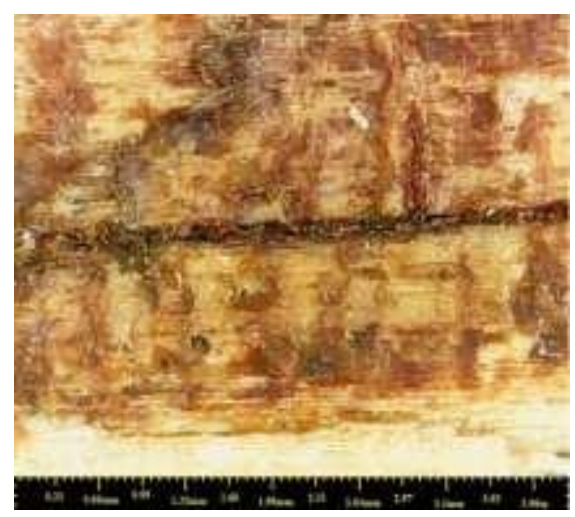

Figure (5-4) digital microscope Figurefrom Figure (5-2) shows that some cracks, corrosion and defiberation.

Digital microscope images shows that some cracks, biological deterioration such as(holes, tunnels and different colors), corrosion and defiberation.

\section{Conclusion}

From the field study and sample analysis of some Islamic monuments in both the cities of Alexandria, Rashid, Cairo, Esna and Qus it is evident that:-

1- Wood deterioration occurred in several cases and several factors and their rates vary according to the type of factor:

a) Mechanical factors such as (wind loaded with sand - sea water spray) 
b) Physical factors such as (humidity - temperature)

c) Chemical factors such as (air pollution - salts)

d) Biological factors such as (insect infestation - fungal infection)

2- $\quad$ The cities of Alexandria, Rashid and Cairo suffer from the problem of salts mainly as a result of sewage water, ground water and sea water spray, while the cities of Qus and Esna suffer from an increase in temperature :-

a) Salts and biological factors are the most harmful to the archaeological wood, which is what appeared in the samples of Alexandria and Rashid.

b) Salt damage makes the wood surface fibrous and very weak.

c) Salts have a weak effect on the degree of cellulose polymerization. We observe this by decrease in the intensity of the CO-C spectrum in the absorption area between 1050: $1150 \mathrm{~cm}-1$.

d) Salts have a strong effect on lignin and hemicellulose where we note the disappearance of the spectrum characteristic of it in most samples and its presence is weak in others, on the contrary to samples from Upper Egypt where the distinctive spectrum appears in the samples.

3- $\quad$ High temperatures in Upper Egypt lead to high oxidation, which appears in the form of wood color change and the occurrence of cracks. 
4- $\quad$ The various building materials helped in the damage of the archaeological wood, especially in the coastal environment, which was a catalyst, besides the effect of various damage factors in contrast to Upper Egypt, as it has no role in the damage of wood in desert areas.

5- $\quad$ The coastal environment is more harmful to the archaeological wood than the desert environment, so as to provide all the damage factors that lead to the degradation of the wood in the coastal environment such as salts and biological factors ... etc. Therefore, we can say that desert environment is less damaging to archaeological wood.

\section{Acknowledgements}

We thank the reviewers for their constructive comments. We would especially thank Prof. Dr. Nesrin El Hadidi, Ms Ola Younis, at the Conservation Department, Faculty of Archaeology, Cairo University for their support and assistance in all steps of research, especially in the interpretation the result of FTIR analysis and digital microscope images and Mr. Mohamed Rabie from the Conservation Institute Luxor for his help.

\section{References}

Jelle, B., \& Hovde2, P. (2012). Fourier Transform Infrared Radiation Spectroscopy Applied forWood Rot Decay and Mould Fungi Growth Detection. Hindawi Publishing Corporation, 1-6.

Jingran, G., Jian, L., Jian, q., \& Menglin, G. ((2014)). Degradation assessment of waterlogged wood at Haimenkou site. G. Jingran et alii, 
Frattura ed Integrità Strutturale, 495-501.

Kocaefe, D., Huang, X., Kocaefe , Y., \& Boluk, Y. ( 2013). Study on Weathering Behavior of Jack PineHeat-Treated under Different Conditions. Journal of Energy and Power Engineering 7 (2013) 818-826, 819-825.

Lionetto , F., Del Sole, R., Can, D., \& Maffezzoli, A. (2012). Monitoring Wood Degradation during Weathering byCellulose Crystallinity. materials, 1996-1944.

Pizzo, B., Alves, A., Macchioni, N., \& Giachi, G. (January 2008). Characterization of waterlogged wood by infrared spectroscopy.

Unger , A., Schniewind , A., \& Unger, W. (2001). Conservation of Wood Artifacts. New York: Natural Science in Archaeology.

Anderson, E., Pawlak, z., Owen, N., \& Feist, W. (1991). Infrared Studies of Wood Weathering.Part I: Softwoods. 641-647.

El Hadidi, N. (1997). Treatment and Conservation of Wood - Application on Two Coffins at the Egyptian Museum of the Faculty of Archaeology of cairo university. cairo.

Fawzy, M. (2016). A Comparative Study on the Effect of Cleaning Materials on the ChemicalComposition and Mechanical Properties of Damaged and Undamaged Wood with the Application on Chosen Archaeological Wood. cairo.

Gupta, B., Jelle, B., \& Gao, T. (2014). Wood facade materials ageing 
analysis by FTIR spectroscopy. Institution of Civil Engineers, 219_231.

Gupta, b., Jelle, B., Hovde, P., \& Holme, J. (2011). Characterization of Wood Mould Fungi by FTIR - A Valuable Step for Prediction of Initiation of Decay. XII DBMC, Porto, PORTUGAL, 1-9.

Held, B., Jurgens, J., Duncan, S., \& Farrell, R. (2006). Assessment of fungal diversity and deterioration in a wooden structure at New Harbor, Antarctica. ResearchGate.

Jelle, B., \& Hovde, P. (2012). Fourier Transform Infrared Radiation Spectroscopy Applied forWood Rot Decay and Mould Fungi Growth Detection. Hindawi Publishing Corporation, 6.

Kavkler, K., \& Demsar, A. (2012). Application of FTIR and Raman Spectroscopy to Qualitative Analysis of Structural Changes in Cellulosic Fibres. Original Scienti• c Paper, 19-31.

Lionetto, F; Sole, R; Cannoletta, D; Vasapollo, G; Maffezzoli , A;. (2012). Monitoring Wood Degradation during Weathering by Cellulose Crystallinity. materials, 1910-1922.

Maryandyshev, p., Chernov, A., Lyubov, V., "Ile Trouve, G., Brillard, A., \& Brilhac, J. (2016). Thermal degradation and combustion of wood fuels, coals and hydrolyzedlignin from the Russian Federation: experiments and modeling. Journal of Thermal Analysis and calorimetry, 1388-6150.

Müller, G., Schöpper, C., t Vos, H., Kharazipour, A., \& Polle, A. ( 2009). FTIR-ATR SPECTROSCOPIC ANALYSES OF CHANGES IN WOOD 
PROPERTIES DURING PARTICLE- AND FIBREBOARD PRODUCTION OF HARD- AND

SOFTWOOD TREES. bioresources, 49-71.

Naumann, a., Kües, U., Polle, A., Peddireddi, \& S. (2007). Fourier

Transform Infrared Microscopy in Wood Analysis. ResearchGate, 179196.

Pandey, K., \& Pitman, A. (2003). FTIR studies of the changes in wood chemistry following decay by brown-rot and white-rot fungi. International Biodeterioration \& Biodegradation, $151-160$.

Poletto, M., Zattera, A., \& Santana, R. (2012). Structural Differences Between Wood Species: Evidence from Chemical Composition, FTIR Spectroscopy, and Thermogravimetric Analysis. Journal of Applied Polymer Science, 336-343.

Poni, p. (2007). FOURIER TRANSFORM INFRARED SPECTROSCOPY AND THERMAL ANALYSIS OF LIGNOCELLULOSE FILLERS TREATED WITH ORGANIC ANHYDRIDES. R. BODÎRLĂU, C.A. TEACĂ, 93-104.

Shi, J., Xing, D., \& Lia, J. (2012). FTIR Studies of the Changes in Wood Chemistry from Wood Forming Tissue under Inclined Treatment. Energy Procedia, $758-762$.

Traoré , M; Kaal, J; Cortizas, A;. (2016). Application of FTIR spectroscopy to the characterization of archeological wood. Spectrochimica Acta, 63-70. 
Traoré, M., Kaal, J., \& Cortizas, A. (2016). Application of FTIR spectroscopy to the characterization of archeological wood. Spectrochimica Acta, 63-70.

Wozniak, M., Ratajczak, I., szentner, K., Kwasniewska, P., \& Mazela, B. (2015). Propolis and organosilanes in wood protection. Part I: FTIR analysis and biological tests. Annals of Warsaw University of Life Sciences, 218-224.

Younis, O. (2016). Study on the Effect of Salts on the Structure Of Wood and Methods of Treatment with the Application On a Selected Object. cairo.

Received: February 15, 2018

Accepted: April 20, 2018 